\title{
Access Policy in Capital Account Crises
}




\section{INTERNATIONAL MONETARY FUND \\ Access Policy in Capital Account Crises}

Prepared by the Policy Development and Review and Treasurer's Departments

In Consultation with Other Departments

Approved by Timothy Geithner and Eduard Brau

July 29,2002

Contents Page

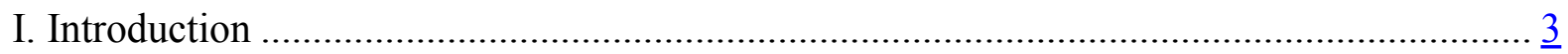

II. Summary of Experience in Past Exceptional Access Cases ....................................... $\underline{8}$

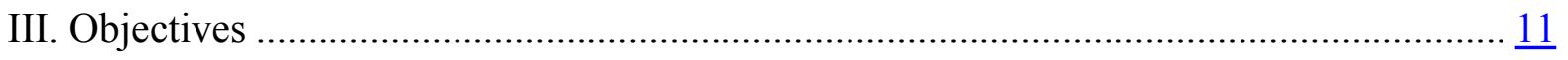

IV. Circumstances For Access Above the Limits ........................................................ $\frac{12}{12}$

A. The Current Limits............................................................................. $\frac{12}{12}$

B. Criteria for Exceptional Access............................................................. $\frac{13}{13}$

V. The Appropriate Scale of Access .................................................................... 14

Quotas and alternative metrics ...................................................... $\frac{17}{17}$

VI. Elements to Constrain Exceptional Access ….................................................... 18

A. Procedures for Exceptional Access Decisions ............................................ $\frac{21}{23}$

Supermajority approval of exceptional access......................................... $\frac{23}{23}$

B. An Exceptional Access Limit or Norm ……............................................... 23

C. Prudential Considerations …............................................................. $\frac{25}{25}$

Strengthened analysis of Fund exposure and risks ............................... $\frac{25}{26}$

A maximum exposure limit ..............................................................

VII. The Terms and Conditions of Exceptional Access ….......................................... 27

VIII. The Next Steps and Issues for Discussion ..................................................... $\underline{30}$

Boxes

1. Brief Summary of Policies on Access to Fund Resources.............................................. 4

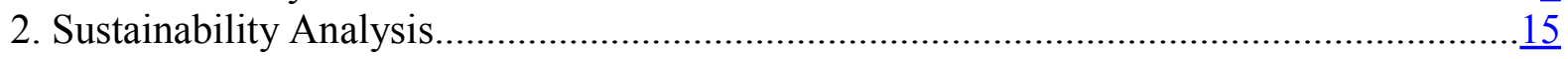

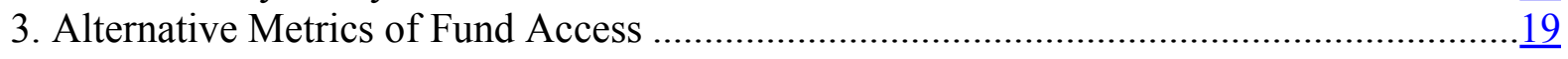

4. Burden Sharing and Exposure Limits .................................................................. 
Table

1. Exceptional Access in Fund Arrangements, 1995-2002 ................................................

Annex I

The Prague Framework for Private Sector Involvement

Annex II

An Overview of Past Exceptional Access Programs

A. The Amount of Fund Support in the Exceptional Access Cases ......................... $\frac{33}{37}$

B. Some Outcomes of Exceptional Access Programs ......................................... $\frac{37}{37}$

The attainment of external viability ...................................................... $\frac{37}{42}$

Securing capital market financing ...................................................... 42

Has exceptional access under Fund arrangements added to moral hazard? ...... $\underline{46}$

Annex III

Sustainability Analysis of Past Exceptional Access Programs

Annex Figures

1. Fund Arrangements $\underline{35}$

2. Fund Commitments $\underline{36}$

3. Composition of Financing Packages in High Access Cases.

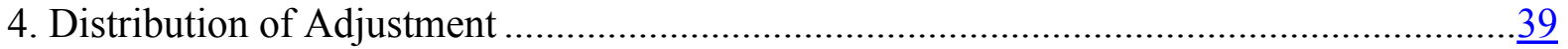

5. High Access Cases: Selected Indicators ............................................................... $\frac{41}{43}$

6. High Access Cases: Selected Indicators .................................................................... 43

7. Market Access Indicator for Selected High Access Cases .......................................... 44

8. Market Spread Before and After IMF Arrangement for Selected High Access Cases......... $\underline{45}$

9. Sensivity Analysis for External Debt-to-GDP Ratio ............................................... 50 


\section{INTRODUCTION}

1. Increasing integration of global financial markets in the last decade has helped to finance a rapid expansion of investment and activity in emerging market countries, but has also exposed these countries to rapid reversals of capital flows and crisis. The Fund's decisions to lend to member countries in amounts well above the access limits for Mexico (1995), and since then, have raised important questions about the role of the Fund in crisis resolution and the appropriate size of Fund access in capital account crises. This paper reviews past experience in exceptional access cases and considers strengthened conditions, procedures and safeguards for guiding decisions on Fund programs in these exceptional circumstances where Fund financing above normal access limits may be appropriate.

2. The Fund's policies on access discussed in this paper are part of the ongoing work to strengthen the framework for crisis prevention and resolution. The Fund needs to preserve the capacity to lend in exceptional circumstances above normal access limits under adequate safeguards, in situations where this can help a member country address its problems. In many cases, however, this will not be the appropriate course of action. The crisis resolution strategy also includes development of an improved framework for debt restructuring for dealing with situations where debt can only be brought to a sustainable position with a restructuring. Work is ongoing on the Sovereign Debt Restructuring Mechanism (SDRM), collective action clauses, and the Fund's policies for lending into arrears. ${ }^{1}$

3. Only a small proportion of Fund arrangements have access above the limits, but these represent a large share of total Fund exposure. Arrangements to use the Fund's general resources in the period since 1995 can be divided into two groups. Most of the arrangements ( 88 percent) are within the normal access limits under the credit tranches and the EFF (Box 1), where the average annual access is between 40 and 50 percent of quota. Access policy in such cases remains as discussed in the 2001 review, and changes in this policy are not contemplated in the present paper. ${ }^{2}$ On the other hand, most of total Fund exposure outstanding has been committed in support of a small number of large arrangements for members experiencing capital account crises - the "exceptional access

\footnotetext{
${ }^{1}$ See Sovereign Debt Restructuring Mechanism -- Further Considerations (forthcoming); Collective Action Clauses in Sovereign Bond Contracts-Encouraging Greater Use, June 7, 2002 (SM/02/175); The Design and Effectiveness of Collective Action Clauses, June 7, 2002; (SM/02/173) and Fund Policy on Lending into Arrears to Private CreditorsFurther Considerations of Good Faith Criterion (forthcoming).

${ }^{2}$ Review of Access Policy in the Credit Tranches and Under the Extended Fund Facility August 8, 2001 (EBS/01/133).
} 
cases" (Table 1). ${ }^{3}$ In providing such exceptional access the Fund has appealed to "exceptional circumstances," or lent through the Supplemental Reserve Facility (SRF) under which there are no defined access limits.

\section{Box 1. Brief Summary of Policies on Access to Fund Resources}

The Fund's access policy is based on a system of criteria for choosing access levels in specific cases and limits on access.

- Criteria for access are: (i) the member's actual or potential balance of payments need, (ii) the ability of the member to service its indebtedness to the Fund (which is partly based on the strength of the program), and (iii) the amount of the member's outstanding use of Fund credit and its record in using Fund resources in the past.

- $\quad$ Access limits under credit tranches and the Extended Fund Facility (EFF) are subject to an annual limit on gross purchases currently set at 100 percent of quota, and a cumulative limit on credit outstanding currently set at 300 percent of quota. Access can exceed these limits in "exceptional circumstances," which are not further defined.

- The Supplemental Reserve Facility (SRF) and Contingent Credit Lines (CCL) are not subject to defined access limits, but commitments under the CCL are expected to be in the range of 300-500 percent of quota.

- $\quad$ Special criteria and limits also apply to the policy on emergency assistance for natural disasters and for post conflict cases, to the Compensatory Financing Facility (CFF), and to the Poverty Reduction and Growth facility (PRGF). These facilities are not discussed in this paper.

A more detailed description of current policies on access is contained in Review of Access Policy in the Credit Tranches and Under the Extended Fund Facility, op. cit.

\footnotetext{
3 "Exceptional" access is defined in this paper as access above normal limits that apply under the credit tranches and EFF.
} 
Table 1. Exceptional Access in Fund Arrangements, 1995-2002

\begin{tabular}{|c|c|c|c|c|c|c|c|c|c|c|c|c|c|c|c|c|c|c|}
\hline \multirow{3}{*}{ Member } & \multirow{3}{*}{ Circumstances } & \multirow{3}{*}{ Type } & \multirow{3}{*}{$\begin{array}{l}\text { Effective } \\
\text { date 1/ }\end{array}$} & \multirow{3}{*}{$\begin{array}{c}\text { Duration 1/ } \\
\text { (In months) }\end{array}$} & \multirow{2}{*}{\multicolumn{2}{|c|}{$\begin{array}{c}\text { Total Amount 2/ } \\
(\text { SDR bn) }\end{array}$}} & \multicolumn{12}{|c|}{ Total IMF Arrangement Approved in percent of: 4/ } \\
\hline & & & & & & & \multicolumn{3}{|c|}{ Quota 3/ } & \multicolumn{2}{|c|}{ GFN 5/ } & \multirow{2}{*}{$\begin{array}{c}\text { AGFN } \\
\text { Year } 1 \\
6 / 7 /\end{array}$} & \multicolumn{3}{|c|}{ GDP } & \multirow[t]{2}{*}{ M2 } & \multicolumn{2}{|c|}{$\overline{\text { Debt } 8 /}$} \\
\hline & & & & & IMF & Package & Approval & $\begin{array}{c}\text { 11th } \\
\text { Review }\end{array}$ & $\begin{array}{c}\text { Derived } \\
\text { Calculated } \\
\text { 11th Review }\end{array}$ & Program & $\begin{array}{c}\text { Year } 1 \\
6 /\end{array}$ & & & $\overline{\mathrm{MPF}}$ & Package & & Short-term & Sovereign \\
\hline Mexico & New Arrangement & SBA & $2 / 1 / 95$ & 18 & 12.1 & 31.9 & 688 & 467 & 425 & 39 & 39 & 26 & & 4 & 11 & 14 & 34 & 12 \\
\hline Thailand & New Arrangement & SBA & $8 / 20 / 97$ & 34 & 2.9 & 12.5 & 505 & 268 & 157 & 10 & 28 & 6 & & 2 & 10 & 2 & 8 & 63 \\
\hline Korea & New Arrangement & SBA/SRF & $12 / 4 / 97$ & 36 & 15.5 & 42.6 & 1938 & 949 & 434 & 32 & 59 & 15 & & 4 & 12 & 10 & 34 & 54 \\
\hline Russia & Aug. and Ext. & $\mathrm{EFF} / \mathrm{SRF} / \mathrm{CCFF}$ & $7 / 20 / 98$ & 20 & 15.4 & 19.5 & 356 & 258 & 397 & 46 & 73 & 42 & & 5 & 6 & 33 & 83 & 10 \\
\hline Brazil & New Arrangement & SBA/SRF & $12 / 2 / 98$ & 36 & 13.0 & 30.3 & 600 & 429 & 444 & 8 & 18 & 13 & & 2 & 5 & 9 & 21 & 9 \\
\hline Turkey & Augmentation & SBA/SRF & $5 / 15 / 01$ & 19 & 15.0 & 15.0 & 1560 & 1560 & 1316 & 38 & 51 & 36 & & 10 & 10 & 22 & 28 & 20 \\
\hline Argentina & Augmentation & SBA/SRF & $9 / 7 / 01$ & 18 & 16.9 & 21.6 & 800 & 800 & 1240 & 27 & 44 & 39 & & 8 & 10 & 23 & 43 & 15 \\
\hline Brazil & New Arrangement & SBA/SRF & $9 / 14 / 01$ & 15 & 12.1 & 12.1 & 400 & 400 & 414 & 19 & 25 & 14 & & 3 & 3 & 11 & 21 & 7 \\
\hline Turkey & New Arrangement & SBA & $2 / 4 / 02$ & 35 & 12.8 & 12.8 & 1330 & 1330 & 1122 & 23 & 47 & 28 & & 11 & 11 & 23 & 26 & 15 \\
\hline Uruguay & Augmentation & SBA/SRF & $6 / 25 / 02$ & 21 & 1.8 & 1.8 & 571 & 571 & 1474 & 158 & 809 & 20 & 9/ & 9 & 9 & 92 & 37 9/ & 17 \\
\hline
\end{tabular}

Source: Executive Board documents, World Economic Outlook, Government Finance Statistics, and International Financial Statistics.

1/ In the case of augmentations, the date and duration remaining at the time of approval of the augmentation, not initial approval of the arrangement.

2/ In the case of augmentations, includes previously approved amounts, drawn and undrawn, as well as the new augmentation.

3/ Quota at approval uses the quota which was in effect at approval of the arrangement or augmentation, 11th Review is the current quota, and derived calculated 11th Review quota is the result of the strict application of the quota formulas, scaled down by the actual total size of quotas in the Fund.

4/ In percent of GDP, M2, and Sovereign Debt the year before the crisis and short-term debt the year of the crisis.

5/ Gross Fund Financing(GFF)/Gross Financing Requirement(GFR); GFF includes all use of Fund resources during the period under arrangement and associated purchases that were anticipated at the time of approval. GFR is defined as the sum of the current account deficit (excluding grants), amortization on debt with an original maturity in excess of one year including Fund repurchases, the targeted reduction in arrears (in cash as well as through rescheduling) and the targeted buildup in gross reserves. Figures may be estimated based on information available for the period most closely corresponding to the program period.

6/ Measured as the gross financing requirement for the remainder of the initial year plus any part of the next year coverd by the program. Turkey and Argentina include only 2001. Gross Fund financing over the entire arrangement is still used.

7/ Augmented GFN (AGFN) includes the Gross Financing Requirement plus short-term debt on an original maturity basis repaid during the period.

8/ Short-term debt is measured on a residual maturity basis, except for Korea, which is measured on an original maturity basis. Sovereign debt includes gross debt of the consolidated central government, except for Brazil, which is reported on a net basis.

9/ Includes USD 7.0 billion in non-resident deposits in 2001 and USD 2.2 billion in 2002. 
4. Modern capital account crises have posed new challenges, and the Fund has responded to these challenges by strengthening crisis prevention capability and by expanding its capacity to help meet members' unusually large financing needs. ${ }^{4}$ Traditional Fund-supported programs have helped member countries adjust to situations where ongoing macroeconomic imbalances generally result in a relatively gradual deterioration on the external side. In capital account crises, changing market sentiment driven by underlying country vulnerabilities has resulted in sudden and disruptive reversals of capital inflows with high economic and social costs. A strategy combining exceptionally large Fund access (and sometimes other official financing) with economic adjustment and reform by the member was aimed to help restore confidence, slow and stop capital outflows, and support a transition back to access to private capital markets. Fund access was considerably above the quota-based access limits because access within the limits was unlikely to provide sufficient assistance to be effective in the face of the members' exceptional needs.

5. Some of the programs supported by exceptional access from the Fund have been quite successful in meeting objectives, others less so (see Chapter II). All members with such arrangements remain current on their obligations to the Fund, and Mexico, Brazil, Korea, and Russia have made some repurchases ahead of schedule. However, Argentina has recently requested that SRF repurchase expectations be extended, and in Turkey SRF obligations were refinanced with resources in the credit tranches under a successor stand-by. Two countries, Argentina and Russia, ultimately underwent a default by the sovereign, and Korea and Indonesia negotiated a rescheduling of interbank debts. While Argentina, and to a lesser extent Turkey, remain in the midst of crisis, the economic vulnerabilities of the other countries have generally diminished. Most have a stronger current account position than before the crisis, with a more competitive real exchange rate, while inflation remains low and growth is resuming. However, external debt remains above pre-crisis levels and remains a particular vulnerability in Brazil, Indonesia, and Turkey. While the interruption of private financing was generally longer than expected, Brazil, Korea, Mexico, Thailand and to some extent Russia have renewed access to private markets, albeit in some cases on stiffer terms than previously.

\section{The use of exceptional Fund access has raised a number of potential concerns:}

- $\quad$ The potential availability of exceptionally large access from the Fund may add to moral hazard in the system. It may make private creditors insufficiently attentive to the inherent riskiness of their investments. This may make for less efficient markets and less efficient pricing of risk.

\footnotetext{
${ }^{4}$ See Ghosh, Lane et. al., IMF-Supported Programs in Capital Account Crises: Design and Experience, Occasional Paper No. 210, 2002.
} 
- $\quad$ The lack of clarity that exists in the present framework may have contributed to increased uncertainty in the system. In particular, observers cite uncertainty about (i) the circumstances in which exceptional access to Fund resources may be possible, (ii) the scale of exceptional access, and (iii) the basis for decisions about when Fund financing is likely to be accompanied by some restructuring of private claims.

- $\quad$ The degree of discretion and flexibility in the present framework may make the Fund more vulnerable to pressure to provide exceptional access even when prospects for success are quite poor and debt burden of the sovereign is likely to be unsustainable.

- $\quad$ Exceptional access to a few large members has led to a significant increase in credit concentration in the Fund which increases the risks to the financial position of the Fund in case the economic and financial situation of members does not improve as expected.

7. With this background in mind, the present review sets out for the Board's consideration possible elements of a strengthened framework for exceptional access policy. The presumption should remain that most Fund-supported programs would continue to have access well within the access limits. However, recognizing that there are circumstances that would justify exceptional access, enhanced delineation of these circumstances is warranted, with emphasis on a positive assessment of prospects for debt sustainability (Chapter IV). For those countries that meet the criteria, it may also be possible to better identify need and the appropriate scale of access, although large uncertainties will remain, and alternative metrics to quotas may provide additional perspectives (Chapter V).

8. Given the inherent uncertainties in determining the appropriate scale of access, other safeguards may be appropriate to guard against inappropriate recourse to exceptional access. Improving the processes by which decisions about exceptional access are made by the Fund would contribute to more transparency and accountability. Requirements to raise the burden of proof could include further information on risks to the Fund and Fund exposures, procedures for ex post review, and a presumption that staff reports would be published. The paper also considers several other options for access policy, including a presumptive limit on exceptional access, formal constraints on Fund risk exposure, and a requirement for a supermajority at the Board to approve exceptional access (Chapter VI). Some options under consideration might suggest a change in the terms and conditions applying to Fund lending in exceptional access cases (Chapter VII).

9. The options for access policy set out in this paper are broadly consistent with the Prague Framework for involving the private sector in resolving financial crises. ${ }^{56}$

${ }^{5}$ The Prague framework is set out in Annex I.

${ }^{6}$ This paper does not emphasize the use of such intermediate forms of PSI, often involving moral suasion, as their effectiveness has often been shown to be limited in recent cases. 
Consistent with the framework, additional constraints are proposed to ensure that extraordinary access would be exceptional, and would presume substantial justification. The substantive conditions identified here would help inform judgments about when concerted private sector involvement to restructure or reduce debt would be necessary to achieve financial sustainability. Fund lending in this eventuality would fall, initially, under the lending into arrears policy.

\section{Summary of Experience in Past exceptional Access Cases}

10. Experience with past exceptional access cases provides a useful basis for considering changes in access policy. This chapter focuses on some of the key questions that have been raised about the Fund's lending in the exceptional access cases: whether the Fund-supported program brought the member to a sustainable external position; whether an early return to private capital market financing was achieved; and whether the Fund's involvement added significantly to moral hazard for creditors or other potential borrowers. A more comprehensive treatment of these issues is contained in Annex II.

\section{Using various measures, the Fund lent more in exceptional access cases than it has in any previous arrangements in its history (Table 1):}

- In terms of quota, access committed under these arrangements averaged over 500 percent of quota at the time and was as high as 1,938 percent in the case of Korea.

- $\quad$ Reflecting the size of their economies, Fund support for individual countries was also very substantial in terms of absolute amounts (up to SDR 16.9 billion in the case of Argentina).

- Access in most cases accounted for a substantial share of the Fund's outstanding and total usable resources at that time. The Fund's commitment has been as high as 36 percent of outstanding Fund credit (Mexico).

- $\quad$ As a share of gross financing needs (GFN) at the time of the approval, access ranged from about 10 percent (in Brazil and Thailand) to about half (in Russia), and much higher in the recent case of Uruguay. ${ }^{78}$ This is significantly higher than in programs

${ }^{7}$ GFN is defined as the current account balance excluding official transfer receipts, plus Fund repurchases, plus other amortizations of maturities in excess of one year, plus targeted arrears reduction, plus buildup of gross reserves.

${ }^{8}$ In most cases, approved access as a share of ex post gross financing was higher since the capital account was poorer and current account adjustment greater than programmed. Indeed, the current account adjusted far more than was needed to achieve any reasonable measure of sustainability, and this excessive adjustment was brought about mainly through the effects of severe recessions on imports. 
with access below the limits, where the Fund meets on average 11 percent of GFN. In part, this reflects the characteristics of capital account crises, where the prevailing definition of GFN fails to measure actual total balance of payments need.

- $\quad$ Access was heavily frontloaded in all cases, and especially when SRF resources were used. The average length of arrangements was $2 \frac{1}{2}$ years, and in all cases more than 70 percent of total access, and in several cases more than 80 percent was made available during the first year of the arrangement.

\section{Despite being high in relation to past practice, access to Fund resources was} small relative to the ex post adjustment. Fund support in these cases was also significantly lower than total ex ante potential balance of payments need, although higher than in other arrangements. In the early exceptional access arrangements, Fund support was supplemented by commitments from other multilateral and official bilateral creditors; more recently this has fallen away, e.g. in the case of Turkey.

13. Measured by the simplest indicator of viability - capacity to repay the Fund without strain - outcomes so far have mostly been positive. In all cases, the borrowing members have remained current on their obligations to the Fund, and Brazil, Mexico and Korea were able to repay the Fund in advance of scheduled dates. The Fund has been repaid, or largely so, by Korea, Mexico, and Russia. Indonesia has only started to repay. Turkey, the largest Fund exposure, has yet to start repaying, and Argentina still faces acute financial pressure.

14. Some perspective on whether the magnitude of the Fund's lending was broadly appropriate can be derived from the effects of the Fund's support. The extent to which the amount of Fund financial support made a difference relies on a counterfactual and cannot be observed and it is therefore not possible to know whether exceptional access was in itself crucial in any single case. ${ }^{9}$ However, in most of the countries concerned it was evidently enough to help them avoid default, but not enough to help them avoid very substantial adjustment.

\footnotetext{
${ }^{9}$ Some comparative analysis has been conducted of the case of Malaysia, which adopted similar policies to those in Thailand, Indonesia and Korea, but did not have Fund financial support for its adjustment efforts. However, the analysis has focused mostly on the effects of controls on capital outflows, which Malaysia adopted and the other countries did not. There were also differences in the initial position. In particular, Malaysia's external debt at the outset of the crisis was only 17 percent of GDP, its initial fiscal position was strong, and the regulatory framework for the financial sector was relatively well developed. See $I M F-$ Supported Programs in Capital Account Crises, op. cit., and Capital Controls: Country Experiences with Their Use and Liberalization, IMF Occasional Paper 190, 2000.
} 
15. The results of programs in achieving external viability, economic outcomes and limiting vulnerability is mixed. The programs did not generally have immediate success with respect to the objectives which were used to justify exceptional access: restoring confidence, stabilizing capital flows, and preventing a large overshooting of the exchange rate, and in retrospect it was probably not reasonable to expect such an early reversal of confidence. Experience suggests that just as the causes of the crises took time to build up, their resolution also took time, and the pace of the recovery was dependent on the quality of the political leadership, the economic policy management, and the external environment. However, most of the 1990s crisis countries are in a stronger position now than they were before the crisis. Much of this strengthened position is due to their own adjustment efforts, but it is also likely that Fund financial support played a substantial part in helping them through the crisis. However, in many of the countries significant vulnerabilities remain. The rise in the debt ratios of Indonesia and Brazil is disquieting, as is the uncompleted structural agenda, coupled with higher debt ratios, in several other countries.

16. In some countries the adjustment and exceptional access in the context of the associated political and external environment were not sufficient to avoid a restructuring of obligations. Both Russia and Argentina defaulted on their debt shortly after approval of augmentations of their Fund arrangements, and Indonesia and Korea rescheduled bank debts. The restructurings in Argentina and Russia raise the question of whether the default was already unavoidable at the point the augmentations were approved and whether an alternative strategy to the design of the program and the use of exceptional access should have been adopted.

17. The record of the exceptional access programs in bringing about a resumption of private market financing is also mixed. In some cases, the hoped-for rapid turnaround in the capital account was not realized. Those countries that did not default now have renewed access to capital markets, although on less favorable terms than before and in more limited quantities. But this may reflect reduced demand for credit as much as reduced supply, since many of the crisis countries are now justifiably cautious about borrowing too much. However, debt flows into emerging markets are now significantly less abundant and investors in emerging markets are more discriminatory then before.

18. Some moral hazard is inevitable in Fund lending, but there is little evidence that the use of exceptional access in general has large effects on investor behavior. The Fund's support - even including other official funds - in these cases has been on an insufficient scale to constitute a full bailout of private creditors. ${ }^{10}$ The continuing high level

${ }^{10}$ For a more comprehensive discussion of this question, see Lane and Phillips Does IMF Financing Result in Moral Hazard, IMF Working Paper No. 00/168, October 2000, and Kamin Identifying the Role of Moral Hazard in International Financial Markets, draft Federal Reserve Board, December 2001; Dell' Ariccia, Gödde and Zettelmeyer Moral Hazard and International Crisis Lending: A Test, draft, November 2000. 
of spreads, their increased dispersion, reduced cross correlation, and greater responsiveness to changes in fundamentals suggests that expectations of a bailout from the Fund are not an overriding factor in investor decisions. Also, the decline in net private credit flows to emerging markets, the substantial adjustment undertaken across emerging markets since 1997 and the preference for self-insurance in the form of high reserves do not seem to justify the conclusion that the potential availability of large scale financial support from the Fund by itself has substantially increased moral hazard in the system.

\section{OBJECTIVES}

19. More clearly defined criteria regarding the appropriate use of exceptional access would be useful for a number of reasons. They could help shape the expectations of members and markets, as well as provide clearer benchmarks for the difficult decisions on program design and access that have to be made. They could perform a useful role in safeguarding the Fund's resources, in controlling the Fund's assumption of risk, and in helping ensure uniformity of treatment. In addition, more clearly defined criteria would help to ensure that there are adequate safeguards against a risk that exceptional access is generalized to cases where it is not appropriate.

20. Criteria for exceptional access need to address the concerns with access decisions in capital account crises that have been identified and learn from experience with the past exceptional access cases. A policy which rests on too-frequent general claims of exceptional circumstances is not satisfactory. The challenge is to find a sensible and credible balance among the following objectives for access to Fund resources above the normal limits:

- $\quad$ To define more clearly and narrowly the conditions under which access above the normal limits may be appropriate, with increasing constraints as higher access is considered.

- $\quad$ To provide a better basis for judgments on the appropriate scale of access in capital account crises, when normal access limits in terms of present quotas may be too constraining.

- $\quad$ To provide more clarity on the criteria used by the Fund to determine cases where it may be appropriate to consider access above normal limits or where a restructuring of private claims is necessary.

- $\quad$ To put in place greater internal safeguards to ensure these judgments are made carefully, that the risks involved are appropriately weighed, that the Board has sufficient involvement.

- $\quad$ To preserve the Fund's financial position and safeguard its resources. 


\section{Circumstances For AcCess Above the Limits}

21. This section considers how the criteria for lending above the limits could be better defined and tightened, to give additional confidence that exceptional access would be used consistent with the above objectives.

\section{A. The Current Limits}

\section{The access limits under the credit tranches and EFF fulfill several objectives:}

- The annual access limit is intended to ensure that members hit by typical shocks do not rely excessively on Fund financing, but adopt appropriate adjustment measures as well. At the same time, the annual limit must be high enough to provide confidence to members that they will be able to weather shocks without having to resort to excessive adjustment. The annual limit also serves to share the burden of financing a typical shock with creditors other than the Fund, so that the Fund's catalytic role is assured, and to ensure that members do not exhaust their total potential access to the Fund more rapidly than would be warranted by the typical frequency and size of shocks.

- The cumulative access limit is intended primarily as a rationing device for Fund resources, to ensure that borrowers are never treated on a "first-come-first-served" basis. It is also designed to ensure that members do not become unduly indebted to the Fund.

\section{Access above these limits has been approved because there were "exceptional} circumstances," or under the SRF. The cases where exceptional circumstances can be invoked have not been pre-specified by the Board. For the SRF, a circumstance test has been established to limit its use to members facing balance of payments problems related to capital account crises. Furthermore, decisions on the amount of financing under the SRF depend on the criteria set out in Box 1 above, the member's record in cooperating with the Fund in surveillance, and the Fund's liquidity. ${ }^{11}$

\footnotetext{
${ }^{11}$ The SRF can be used by "a member that is experiencing exceptional balance of payments difficulties due to a large short-term financing need resulting from a sudden and disruptive loss of market confidence reflected in pressure on the capital account and the member's reserves, if there is a reasonable expectation that the implementation of strong adjustment policies and adequate financing will result, within a short period of time, in an early correction of such difficulties." See Decision No. 11627-(97/123) SRF, December 17, 1997.
} 


\section{B. Criteria for Exceptional Access}

24. There is scope for establishing more explicit criteria under which exceptional access might be made available. The aim would be to identify criteria which would provide as much clarity as possible in defining cases where exceptional access in financial crises was appropriate, and where it was not. The following criteria, each of which would have to be met to support justification for a program with exceptional access, are proposed:

- The member is experiencing exceptional balance of payments pressures on the capital account resulting in a need for Fund financing that cannot be met within the normal limits. Such a BOP need could be expected to be reversed over the near term. ${ }^{12}$ Fund financing in such a case may help to attenuate adjustment costs and reduce the impact of the domestic recessions that accompany capital account crises.

- $\quad$ There is a high probability that debt will remain sustainable, based on rigorous and systematic analysis. Sustainability has been an important component of all requests for use of Fund resources. Based on the strengthened standards for such analysis, rigorous and systematic sustainability assessments will be particularly important in exceptional access cases (Box 2). ${ }^{13}$ Such considerations are especially critical if the initial debt stock is very high and adjustment required to restore sustainability is very large. In such cases, exceptional access may not be appropriate.

- $\quad$ The member has good prospects of regaining market access, so that the Fund financing would provide a bridge. Consistent with the Prague framework, Fund financing should be limited to cases where the restoration of market access on terms consistent with medium-term external sustainability is realistic in a reasonable timeframe. This criterion is intended to ensure that Fund financing provides a bridge to a return to appropriate market access.

- The policy program of the member country provides a reasonably strong prospect of success, including not only the member's adjustment plans but also its institutional and political capacity to deliver that adjustment. The ability of the member to implement necessary policy adjustments will also be judged based on the

\footnotetext{
${ }^{12}$ A member that is experiencing such pressures may decide not to draw available resources immediately (Brazil, 2001). While the current system allows the Fund to approve precautionary arrangements that provide for exceptional access, it may be worthwhile to consider, at a later stage, such arrangements explicitly (including precautionary SRF arrangements), and the implications for the CCL.

${ }^{13}$ Assessing Sustainability, SM/02/166 (May 28, 2002).
} 
nature and appropriateness of the exchange regime, and the member's past experience with adjustment and record of use of Fund resources. ${ }^{14}$

\section{Regional and systemic implications have often been cited as a potential}

justification for exceptional access. In this vein, the SRF decision states that the facility is likely to be used when there is a threat of contagion, although threat of contagion does not affect eligibility or access under the facility. In addition, NAB and GAB borrowing can be activated where Fund resources need to be supplemented to reinforce the stability of the international financial system in the case of a systemic threat. However, it would be inappropriate to make the systemic criterion a necessary or a sufficient condition for providing exceptional access. Such a criterion would create situations where larger countries had access to higher amounts of Fund financing, in relation to quota, which may be inconsistent with uniformity of treatment under the Articles of Agreement, and could also magnify perceived moral hazard risks with regard to large emerging market members. ${ }^{15} \mathrm{~A}$ systemic test (however specified) should not be used to justify exceptional access in circumstances where the other criteria were not met. For example, if the debt burden were high and the program adjustment would not allow reaching sustainability in the medium run, exceptional access based solely on the fact that a crisis could have systemic effects would not be appropriate. Similarly, a member that did not meet the systemic criteria should not on this basis be denied exceptional access, if the other substantive conditions established above are satisfied.

\section{The Appropriate Scale of ACCess}

26. A member's balance of payments need is a key criterion in determining access in individual cases. To obtain access to Fund resources, a member must represent that it has a need because of its balance of payments or its reserve positions, or its developments in reserves (Article V, Section 3(b)(ii)). The condition of need can be satisfied if any of the three criteria are met. Application of these criteria requires considerable judgment. ${ }^{16}$

${ }^{14}$ The latter is a standard criterion for determining access.

${ }^{15}$ Uniformity is the basic legal principle that governs all the activities of the Fund. This principle is based on the Articles of Agreement, which, with very limited exceptions (Article V, Section 8(c); Article V, Section 12(f) (ii) and (iii)), establish the same rights and obligations for all members. Moreover, some provisions in the Articles are specific in declaring that uniformity must be observed (Article II, Section 2, second sentence, on membership terms; Article V, Section 8(d), on charges; Article V, Section 9(a), on remuneration).

${ }^{16}$ See Need as a Condition for Use of Fund Resources, SM/94/299, December 16, 1994. 


\section{Box 2. Sustainability Analysis}

Access to Fund financing, and exceptional access in particular, is conditioned on assurances that under reasonable scenarios the situation will be sustainable. One key role of the sustainability decisions analysis is to determine whether exceptional Fund financing can support a plausible adjustment path that would lead to a sustainable situation in the medium term, or alternatively whether the Fund can only help in the context of a debt restructuring. Sustainability decisions are key in determining a member's capacity to repay the Fund without undue risk.

The assessment of sustainability has recently been revisited to strengthen the elements of the analysis and to put them in a common framework. The framework includes three main elements: (i) a set of standard indicators of debt and debt service; (ii) staff's baseline medium-term projections with clearly presented assumptions; and (iii) standard sensitivity tests around the baseline. ${ }^{1}$ Such a standardized approach is useful to ensure conceptual consistency of sustainability analysis across countries, but country specifics also need to be taken into account when making judgments about sustainability in individual cases.

Maintaining adequate financing during a Fund-supported program is another aspect of sustainability. Some programs with adequate policy implementation may fail to restore confidence and the country may face a larger than originally expected financing gap, due to the higher interest rates and/or a shortfall in external financing. While these considerations may arise in any program, the risks are exceptionally high in capital account crises. It will be therefore crucial to review financing assurances in the context of program reviews.

${ }^{1}$ Annex III provides a summary of retrospective sensitivity analysis for the six recent exceptional access cases where there has been sufficient time to evaluate the outcome.

27. Assessment of balance of payments need in financial crises is particularly difficult. The size of the balance of payments shocks that can affect countries that are integrated into capital markets and have accumulated a substantial stock of debt, tends to be larger and more uncertain than in the conventional current account crises. In these cases need also tends to be in excess of what can be provided within the normal access limits given current quotas. The maturing short-term debt and demands to hedge currency exposure stemming from the existing stock of debt can both augment pressure on the balance of payments. Identifying need in such an environment has been particularly fraught, as problems have erupted suddenly and on an unprecedented scale, and the conditions necessary for increasing private sector confidence are hard to determine with certainty. 
28. The gross financing needs (GFN) variable, which is a commonly used measure of need in standard Fund programs, has a number of limitations:

- There is a circularity in defining GFN. By the time the program is agreed, the financing need cannot exceed the financing available.

- $\quad$ The traditional concept of GFN does not cover balance of payments needs arising from the capital account. An augmented gross financing need concept has been defined, but projections of capital flows are highly uncertain. ${ }^{17}$

- $\quad$ Should a gross or net financing need concept be used? Some of the elements of the gross needs are netted out or are self financing (such as FDI and related imports).

29. Stocks of financial claims can be very large and could potentially translate into large balance of payments need. The scale of need in financial crises depends on the willingness of investors - both residents and non-residents - to continue to hold financial claims on the country facing difficulties. In the event of a major collapse of confidence, the potential balance of payments effects can swamp available resources. The risk of a broad collapse of confidence is particularly acute if a crisis snowballs across sectors. For example, the difficulties a government faces refinancing its debts can trigger a loss of confidence in the banking sector. The objective is to take action early on to reassure investors, and thus to limit systemic consequences. In such circumstances, early Fund assistance may prevent a problem that could otherwise become too large.

30. Even when the need is large, it does not necessarily have to be fully covered by Fund financing. In many cases, addressing the crisis will require adjustment to reduce the scale of the potential need, including needs arising from the capital account. For example, depreciation of the currency can help to equilibrate the demand for local and foreign assets. But when adjustment costs are high, and external assistance can help a country smooth its adjustment to the deterioration in the balance of payments, there may be a case for external financing.

31. Financing from private creditors and investors as well as from the official sector will often be crucial to meeting the country's financing needs. The success of the program will depend on the continued willingness of investors to hold a range of local assets and to roll over maturing debts. The behavior of private creditors and investors directly affects the scale of the projected capital outflows, and thus the scale of the potential financing need. In

\footnotetext{
${ }^{17}$ Narrow GFN comprises current account deficits, excluding official transfers and amortization of medium and long-term loans (including Fund repurchases). Broad GFN includes, in addition to narrow GFN, reserve accumulation and arrears clearance. Augmented GFN is narrow GFN plus short-term debt outstanding. However, projections of short-term debt flows are highly uncertain.
} 
some cases, the member's debt may be unsustainable, or its immediate financing needs may exceed the scale of available official support, and the member may need to seek a debt restructuring from its private creditors to provide some of the needed financing. Here, the Fund would only be willing to lend its resources in the context of efforts by the member to restructure its private debts to provide the financing needed for the member's Fund-supported program to work.

32. Fund financing in exceptional access cases has in practice covered only a portion of the gross financing need with private sector financing and from other official creditors filling the balance. As noted, in many cases the expected resumption of private financing has not materialized as early as expected, private sector involvement based on moral suasion has often proved ineffective, and ex post adjustment exceeded the program projections. However, a policy to require concerted or involuntary action from private sector creditors as a condition for exceptional access could undermine the return of confidence and the resumption of access to private capital that is the objective of the program.

\section{In general, Fund financing should be expected to be the main source of official}

financing in capital account crises. At the same time, other official financing from multilateral sources will often be involved to support key structural and social measures, and there are some circumstances where bilateral finance may be appropriate alongside the Fund, such as when the Fund's exposure would otherwise be too high or if it is liquidity constrained.

\section{Quotas and alternative metrics}

34. The Fund's access criteria and limits are based on quotas. Quotas are fundamental to the Fund's role as a financial institution and are based on member's relative economic size. Quotas determine each member's maximum commitment to provide resources to the Fund to assist in financing other members with a balance of payments need. Quotas also serve as the basis for voting rights in the Fund, consistent with the view that decision making in the institution be proportional to the responsibility to provide resources. Finally, an access policy based on quotas ensures uniformity of treatment and preserves the linkages to the other functions of quotas.

35. In capital account crises, access in percent of quotas has varied widely. This is partly due to the difficult nature of assessments about financing needs in these cases. In addition, quotas themselves may not always adequately represent the financing need of a country and the risks to the Fund arising from the Fund's lending. In some cases, the quota may not accurately reflect a country's integration with international capital markets and the magnitude of vulnerability associated with such integration. ${ }^{18}$ This is particularly true for

${ }^{18}$ The Articles of Agreement prohibit use of Fund's resources to meet a large and sustained outflow of capital and allow the Fund to request a member to impose capital controls in order to prevent such use (Article VI, Section 1). Consistent with this, the programs with

(continued) 
emerging market economies. In other cases, the actual quota may significantly diverge from the calculated quota and thus misrepresent the relative size of the economy, in either direction.

36. While access decisions must be based fundamentally on quotas, alternative metrics could provide additional perspectives on the scale of access. Alternative metrics may provide additional information representing the size of the economy, its ability to generate resources and thus the ability of the country to repay the Fund. These variables could include, for example, GDP, exports, and gross reserves. Examination of alternative metrics could suggest either a greater or a lesser size of access than might be suggested by quota alone. To some extent such calculations are already a part of the standard analysis underlying requests for use of Fund resources. Specifically, the capacity to repay tables in staff reports present debt servicing to the Fund in percent of exports, and as a share of overall debt service. These criteria need to be complemented with an assessment of gross financing need and potential claims on the sovereign or its foreign exchange reserves arising from vulnerabilities in the balance sheets of other sectors. Measures of variability of capital movements or further indicators of debt service falling due could be useful (see Box 3 ).

37. Alternative metrics will not provide unequivocal guidance. The use of alternative metrics could not be employed mechanically, but would have to involve significant judgments. For example, a level of access which is reasonable in percent of quota for a particular country but extremely high as a share of GDP might suggest that the capacity to service debt is at risk. But no single alternative metric could adequately cover all the different circumstances that may occur in individual member countries. While quotas are an imperfect anchor for access decisions in capital account crises, no individual alternative metric provides a sufficient alternative, and quotas will remain the basis for the Fund's work.

\section{Elements to Constrain ExCEPTIONAL ACCESS}

38. Improvements in defining the circumstances when, in rare circumstances, access may be justified above limits, could usefully be complemented with additional safeguards. In this context, a number of elements can be considered, including better decision-making procedures, limitations based on the Fund's exposure, and a limit or norm on exceptional access. These elements, discussed further in this chapter, could be introduced individually or jointly.

exceptional access are aimed at restoring confidence with the aim to stop capital outflows, rather than to finance capital outflows themselves. For further discussion of these issues, see Supplemental Reserve Facility, December 5, 1997, EBS/97/225. 


\section{Box 3. Alternative Metrics of Fund Access}

Quota as a measure of the size of Fund access has been at times criticized as an inaccurate metric of the size of lending across members. This is often the case for member countries which are highly integrated with the world economy (particularly emerging markets) or whose calculated quota differs greatly from the actual. Alternative metrics can therefore play a useful role in judging the appropriateness of access levels in all cases, and especially where exceptional access is involved. The analysis below presents some descriptive statistics regarding access relative to alternative metrics comparing the eight exceptional access cases with normal (non-exceptional) access Stand-By and Extended arrangements. ${ }^{1}$

Access in percent of derived calculated quota $\left(11^{\text {th }}\right.$ Review $)$ differed significantly from access in percent of actual quota in several cases (see Figure 1). ${ }^{2}$ First, annual access in percent of derived calculated quota was lower in some exceptional access cases (Thailand, Korea, and Turkey) and higher in others (Russia and Argentina). Second, only half of the exceptional access cases would have exceeded the peak non-exceptional access in percent of derived calculated quota (266 percent in Georgia's 1995 Stand-By arrangement). Third, with the exception of Mexico, there is an apparent drift over time to higher levels of access in percent of calculated quota in each subsequent case. This could suggest that access policy was getting more permissive over time and is consistent with the higher share of Fund financing versus financing by other official creditors in more recent crises.

Alternative metrics to assess the relative size of access can be grouped into those measuring financing need of the member and those measuring member's capacity to repay the Fund. Metrics of need could include access in percent of current account balance, imports, fiscal balance, gross financing need, or external debt; while metrics of capacity to repay could include access in percent of exports, GDP, or gross reserves. However, this distinction is not always clear-cut. For example, the level or phasing of debt service could be a measure of need, as well as signal of the capacity of the member to repay the Fund.

In all cases Fund financing represented only a fraction of ex ante balance of payments need (measured by GFN). For the exceptional access cases average annual access in percent of GFN ranged from a low of eight percent in Brazil and ten percent in Thailand, to 22 percent in Indonesia, 27 percent in Argentina, between 32 and 39 percent in Korea, Turkey, and Mexico, and at the high end, to 46 percent in Russia. This was on average significantly higher than in non-exceptional cases, though the maximum of Fund financing in percent of GFN in these cases was over 50 percent (the Stand-By arrangement for Moldova in 1996).

Access in relation to other metrics (both representing need and capacity to repay) was generally higher in the capital account crises than the average of the non-exceptional cases, though in many cases below the maximum access for non-exceptional cases. Access in percent of private sector debt deserves special attention. The main feature that distinguishes emerging market countries from developing countries is that the former group has access to private capital markets, whereas the latter relies mainly on official financing. This difference is subsequently reflected in the structure of the stock of debt of the two groups, where the larger share of private debt makes emerging markets more susceptible to capital outflows and causes financing needs of substantially higher magnitudes. However, access as a share of external debt to private creditors was much lower for the eight exceptional access cases, even when correcting for countries whose ratios are extremely high due to insignificant levels of private debt. As shown in Annex Figure 1 (Fund access and private debt in GRA supported programs) Fund programs in the capital account crises continued to provide only a fraction of the private stock of debt.

\footnotetext{
${ }^{1}$ In the figure below, non exceptional access cases are divided into quintiles. Observations in the fifth quintile often reflect low levels of the corresponding variable in the denominator. All figures are reported in terms of average annual access.
}

${ }^{2}$ The sum of calculated quotas is larger than actual quotas. Derived calculated quotas were scaled down to the actual total size of the Fund under $9^{\text {th }}$ or $11^{\text {th }}$ Review of Quotas, as appropriate. 
Box 3. Alternative Metrics of Fund Access (continued) 1/
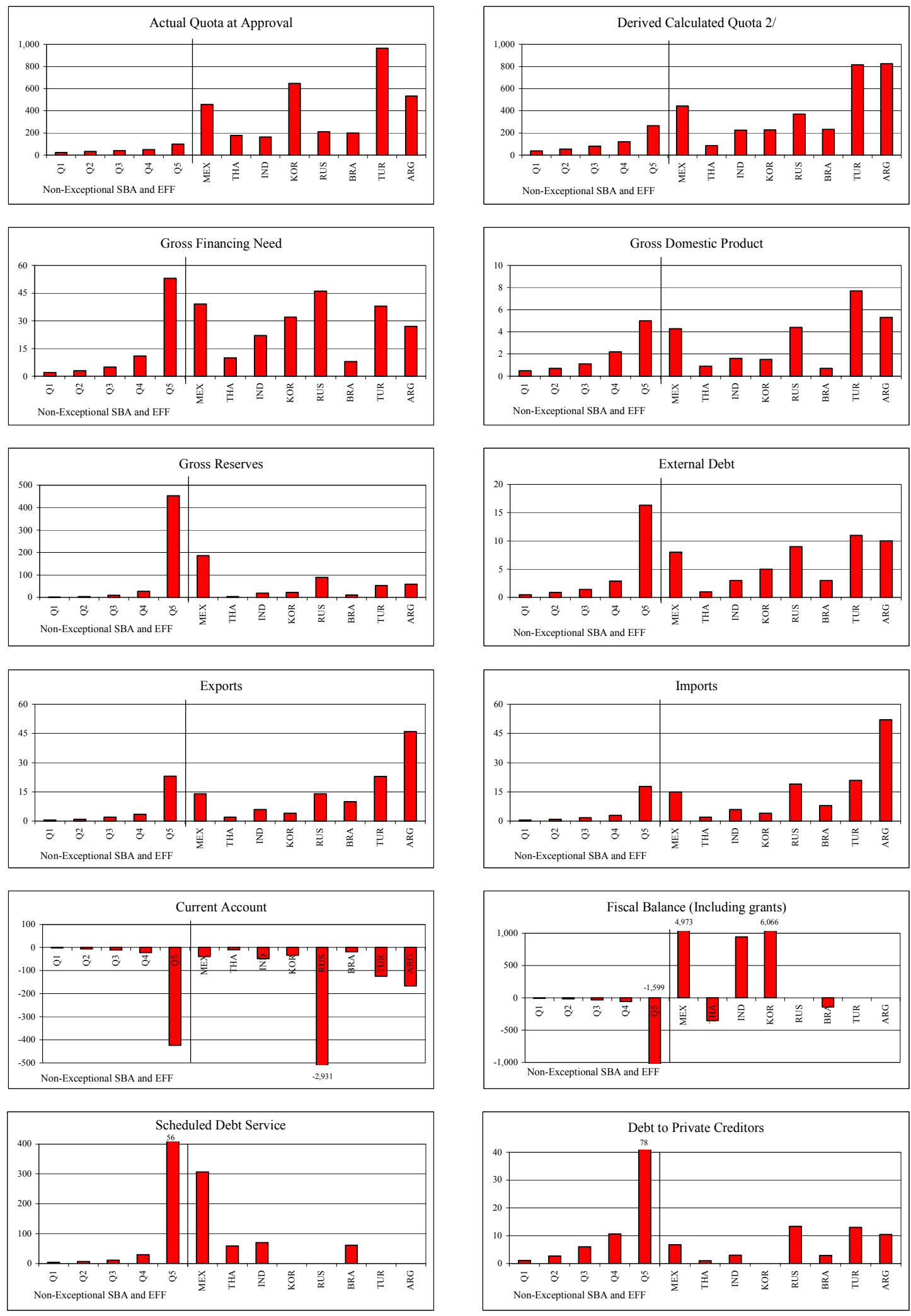

Source: MONA, World Economic Outlook, and staff estimates; Footnotes are shown on previous page. 


\section{A. Procedures for Exceptional Access Decisions}

\section{Formal procedures distinguishing the decision-making process of "normal"} access cases from those for "exceptional" access beyond certain pre-defined limits may be needed. The experience of the last few years shows that capital account crises, in particular, can move rapidly, leading to sometimes rushed decision making. Moreover, when exceptional access is necessary in part to restore market confidence, the analytical basis for access decisions becomes subject to a greater margin of error. The key question then is what can be done to improve the procedures for decision-making.

40. Strengthened procedures for approving access above normal access limits could provide additional layers of protection in exceptional access cases. They would be designed to reinforce the incentives for careful and systematic assessment of sustainability in staff reports, and to give more credibility to the necessary judgment about whether the increase in Fund exposure is prudent in view of exceptional risks involved. The following bullets set out four elements for consideration.

- Raise the burden of proof required in documentation, improving its presentation, and monitoring the access justification guidelines more strictly in the review process. Currently all staff reports are required to provide justifications for the level of access and an assessment of the member's capacity to repay the Fund. However, there is scope for a more extensive treatment of the judgments made and more systematic considerations of risks involved in the documents provided to the Board. Such additional information would be especially useful in exceptional access cases, where the risks are particularly high. In this context, it would be useful for the Board to consider the following documentation requirements in staff reports:

- An extensive treatment of the factors that staff consider relevant for assessment of need and the level of access, a justification for the scale of access and the associated path of reserves, and a forward looking assessment of financial assurances;

- A self-contained standardized analysis of external and fiscal debt sustainability; and

- $\quad$ An assessment prepared by the Policy Development and Review and Treasurer's Departments with a focus on the risks to the Fund arising from the exposure and the Fund's liquidity position.

- Establish requirements on the timing with which the Board is to be informed about the status of negotiations in exceptional access cases. To a large extent, this would codify what is already current practice, under which substantial consultation 
with the Board takes place through informal briefings. ${ }^{19}$ The access policy decision could establish a presumption that, when management and staff reach a point when they consider exceptional access is necessary in a particular case, the Board would be informed about the broad strategy in a special Board meeting before conclusion of discussions with the authorities.

- Establish a stronger presumption of public disclosure. A presumption of publication for use of Fund resources staff reports could be established for exceptional access cases, in order to provide greater transparency on the strategy adopted in the program. In line with the current publications policy of the Fund, members have the right to request deletion of market sensitive information from the published version of the documents.

- $\quad$ Require an ex post evaluation of exceptional access decisions. This option would set an explicit requirement for a public review by the Fund to raise accountability. ${ }^{20}$ In practice, such reviews have already become more or less expected. The main benefit of a formal policy would be a degree of uniformity of treatment (no large program could escape being evaluated). Such an evaluation should be conducted by the staff a year after the end of the arrangement. The aim would be to determine whether justifications presented at the outset of the individual program were consistent with Fund policies and to review performance under the program. It would be also useful to complement such staff assessments with external evaluations focusing on cross-country comparisons, which could be conducted by the Fund's Independent Evaluation Office (IEO) should they decide to do so, and/or by external evaluators.

41. These procedural elements would provide requirements to improve the present practice and help ensure that adequate care is exercised in decision making for exceptional access. These elements would be relatively simple to implement, and require only a simple Board majority.

19 The Emergency Financing Mechanism (EFM) provides for exceptional procedures that, in the event a member faced a crisis, would facilitate rapid approval of Fund support while ensuring the conditionality necessary to warrant such support. The EFM, however, does not necessarily cover all cases of exceptional access, as the trigger is the use of emergency procedures, not the level of access. The EFM has been used less frequently in recent crises as ongoing consultations have been the norm. See Summing up by the Chairman: Emergency Financing Mechanism Executive Board Meeting 95/85, September 12, 1995.

${ }^{20}$ The Fund has conducted an unpublished review of the Mexico crisis, a study of the Asian crisis IMF-Supported Programs in Indonesia, Korea, and Thailand: A Preliminary Assessment, IMF Occasional Paper No 178, and a study of the eight capital account crises in the 1990s IMF-Supported Programs in Capital Account Crises, Occasional Paper 210. 


\section{Supermajority approval of exceptional access}

42. In addition to the procedural elements outlined above, a supermajority could be required at the Board for decisions approving arrangements with access above the limits, in order to raise the level of consensus. Requiring a supermajority of, say, seventy or eighty-five percent of the total voting power would ensure that decisions which involve large amounts of Fund resources - and hence are highly consequential for the Fund as well as the member-are only taken when there is a strong consensus for them. While in practice all access decisions are taken by (near) unanimity, an argument could be made that this reflects a voting dynamic that precedes the actual decision, rather than the degree of initial consensus. On the other hand, requiring a supermajority for exceptional access decisions could delay decision making on programs where speed is often critical.

43. The Articles do not allow the Board to set its own voting majority, so a change in the Articles would be required to establish supermajority approval for exceptional access cases. Article XII Section 5(c) states that "Except as otherwise specifically provided, all decisions of the Fund shall be made by the majority of the votes cast." There is no special majority in the Articles for approving exceptional access and it is not within the power of the Board of Governors or the Executive Board to add special majorities to those specified in the Articles. $^{21}$

\section{B. An Exceptional Access Limit or Norm}

44. A presumptive limit on cumulative exceptional access could be introduced to ensure that the Fund's resources are not exhausted, so that borrowers are not treated on a first-come-first-served basis, thus strengthening the role of the normal cumulative limit. Such a limit would also prevent access from drifting into extremely high levels. A presumptive limit or the upper bound of the range could serve as a useful additional constraint on exceptional access. As an alternative to the presumptive limit, a range could be set within which exceptional access would be expected to fall.

45. However, the policy could not absolutely preclude access above this limit without fundamentally constraining the Fund's capacity to respond to crises in its member countries where access above the high limit might be justified.

46. A presumptive limit or range for exceptional access could help to guide access decisions and market expectations, given that estimates of need and the appropriate Fund access are subject to uncertainty. To the degree that a presumptive limit was seen to be effective, it would also help make Fund access decisions more predictable for private markets, reducing uncertainty and possibly contributing to quicker private sector

${ }^{21}$ J. Gold, Voting and Decisions in the International Monetary Fund (1972). 
involvement in difficult cases where restructuring may be needed. ${ }^{22}$ Finally, if the level chosen for the upper presumptive limit were similar to that for the Contingent Credit Lines, the relative incentives to use the CCL instead of waiting to deal with a crisis through other Fund lending would be better aligned.

\section{However, a limit or norm on exceptional access would raise a number of difficult practical hurdles:}

- Choosing the appropriate level for the presumptive limit on exceptional access would involve a difficult judgment. The presumptive limit should be set high enough to allow the Fund to respond usefully in capital account crises, but sufficiently tightly to constrain extremely exceptional access. ${ }^{23}$ As an example, the limit could be established at 500 percent of quota, or a range set at 300-500 percent of quota. This would be consistent with the upper range of access normally expected under the CCL, helping to align incentives under the two facilities. A limit at this level would have constrained six of the exceptional access decisions shown on Table 1. In Korea, and perhaps Turkey, quota was particularly out of line, and access above the presumptive limit would have been likely in any case.

- $\quad$ Access above the high limit would be expected to be used only in extremely rare circumstances. These circumstances could be left unspecified ("exceptional circumstances"), or an attempt could be made to predefine them. If predefined, the conditions would nevertheless need to leave some space for unforeseen circumstances under which a breach might be justified. Given the necessary breadth of predefined conditions, it might indeed be more constraining not to set ex ante the conditions under which access above the high limit would be used.

- The relationship of the normal and exceptional access limits would need to be defined. Under one alternative, the exceptional access limit could be introduced as a complement to the normal access limits. This would effectively create a two-tier system where the exceptional access limit would represent an additional constraint for access. Under a second alternative, the normal access limits could be abolished, and replaced with only one exceptional access limit (for example at 500 percent of quota) applicable to all programs. While the latter approach might appear more equitable, it would likely cause an undesirable upward drift in access in "normal" cases.

${ }^{22}$ On the other hand, some constructive ambiguity in the Fund's lending may help to reduce moral hazard, as with the lender of last resort function of central banks.

${ }^{23}$ A presumptive limit might be derived from prudential considerations, as considered in the next section. 
- The exceptional access limit would need to be related to Fund facilities. The limit could be applied (i) across all existing facilities on all Fund credit outstanding, or (ii) to a particular facility, such as the SRF.

48. Notwithstanding the advantages to an exceptional access limit or norm noted above, such an option would have important difficulties. The problem of choosing the right level for a high limit, and the complexity of rules that would need to be defined around a two-tier system are drawbacks. Furthermore, an exceptional access limit or norm would only be credible to the extent that it was adhered to. The fact that a number of arrangements have already had access at levels that would be exceptions, and the need to leave open the possibility for future exceptions, would raise initial doubts. Finally, there will be pressures in some cases for exceptional access to help rebuild confidence. This could push toward making the presumptive limit a target, or even a floor, instead of a maximum.

\section{Prudential Considerations}

49. Prudential thresholds or assessments for exceptional access could serve to limit the Fund's overall risk exposure to individual countries. While prudential issues have been raised on a case-by-case basis in staff reports for exceptional access proposals, a more systematic and rigorous analysis in all exceptional access cases would be warranted. There are several possible approaches in this regard.

\section{Strengthened analysis of Fund exposure and risks}

50. Information on risks and exposures could be improved. More systematic and comprehensive information regarding the member country's capacity to repay the Fund and the Fund's exposure to the member country would be useful to underpin judgments about the appropriateness of the proposed access levels in individual cases. As part of the information requirements set out above, such reporting could become a standard part of all UFR staff reports in exceptional access cases, or possibly for all UFR staff reports. The included information could consist of the following elements: ${ }^{24}$

- Indicators of Fund exposure (size of the arrangement in percent of the Fund's usable resources, in percent of the Fund's uncommitted usable resources, and the Fund's total credit outstanding).

- A measure of inflexibility of the member country's debt profile (debt and debt service to preferred creditors as a share of total debt and debt service, respectively; the share of collateralized or securitized debt/debt service out of total debt/debt service).

${ }^{24}$ An example of such reporting requirements can be found in the recent Uruguay staff report EBS/02/108. 
- A comparison of these and other standard indicators of capacity to repay the Fund across other exceptional access programs. These would be closely linked to the analysis of sustainability.

\section{A maximum exposure limit}

51. Exceptional access by countries with large quotas has led to a sharp increase in the concentration of credit among a few members and significantly increased the risk profile of the Fund's portfolio. Risks arising from highly concentrated large exposures cannot be ignored from a financial perspective. ${ }^{25}$ The main risk to the Fund is that a single large debtor temporarily could stop payments on its financial obligations to the Fund, leading to a significant adverse impact on its financial position. Such risk cannot be disregarded because the Fund is ill equipped to incur prolonged income losses.

\section{To address the issue of increased risk, the Fund might consider setting a limit on} its maximum absolute exposure to a single member. A maximum prudential exposure limit can be based on the Fund's existing mechanism to share the burden of unpaid charges ("deferred charges"). The Articles of Agreement and Executive Board decisions place limits on burden-sharing. Building on this principle, an exposure limit could be derived such that the Fund could not enter into a commitment to a single borrower that is so large that in the case of arrears on charges the Fund could not fully compensate the income loss from unpaid charges through burden sharing. Full compensation would enable the Fund to continue to remunerate creditor members without potentially large recourse to a draw down of precautionary balances (amounting to SDR 4.9 billion as of April 30, 2002). The level of a maximum exposure limit can be derived from these considerations (see Box 4). ${ }^{26}$ Some judgment would be involved in translating the derived maximum exposure limit, which is specified in terms of credit outstanding, into a nominal figure. The limit could be in the order of SDR 12 billion. $^{27}$ A nominal figure would have the advantage that it would be transparent and stable, and would provide the strongest safeguard of the Fund's financial position.

${ }^{25}$ The External Audit Committee has also called attention to these risks (see: "Briefing of the Executive Board by Mr. Loli, Chairman of the External Audit Committee for FY 2002; FO/DIS/02/196; June 18, 2002).

${ }^{26}$ This derivation of a maximum exposure limit does not take account of possible arrears on principal repayments. The Fund's policies on precautionary balances are the subject of a staff paper scheduled for Board discussion in November 2002.

${ }^{27}$ A limit of SDR 12 billion would be smaller than the exceptional access granted to 8 out of the 11 cases listed in Table 1 . 
53. Establishing a prudential limit would require reconciling the objectives of safeguarding the Fund's financial position and uniformity of treatment of members in terms of access. As the limit would not be specified in percent of quota, it would restrict member countries with large quotas more than those with small ones. As an alternative to the SDR-based limit, a threshold could set in relation to quota and applied uniformly across the membership. However, it would not be possible to justify such an approach on prudential grounds. Ways to reconcile the two objectives would need to be explored further in the next round of discussion.

54. Given the possibility that any maximum exposure ceiling may be exceeded if the Executive Board so decided, additional safeguards could be considered. To take account of the additional risks to the Fund resulting from access beyond a maximum exposure limit, the accumulation of additional precautionary balances through burden sharing could begin whenever the Fund made a financial commitment that could result in a member country's exposure exceeding the maximum prudential limit, with the amounts to be generated linked to the approved commitment of Fund resources above a maximum exposure limit of, say, SDR 12 billion. The burden-shared amounts would be refunded when Fund exposure declined to below the normal access limit. As in the case of burden sharing for unpaid charges, both creditor and debtor countries would bear the burden. Establishment of such a mechanism would require a decision by a 70 percent majority, but the subsequent approval of exceptional access in individual cases would only need a simple majority.

\section{While staff see a number of advantages to such prudential exposure constraints,} there are also drawbacks:

- $\quad$ The derivation of an exposure limit is necessarily judgmental; for instance, the limit would be too high if more countries than one large borrower fell into arrears on charges due to the Fund. This point illustrates the judgmental nature of a maximum exposure limit, since the limit discussed in this paper is not based on a worst-case scenario.

- $\quad$ Accumulation of precautionary balances (as in paragraph 54 above) when the Board approved a financial commitment could be seen as signaling a lack of confidence of the Fund in the members' economic program supported by the use of Fund resources.

\section{The Terms ANd CONDITIONS OF EXCEPTIONAL ACCESS}

56. The terms and conditions of Fund lending above the limits could also be considered as a way to affect incentives that apply to exceptional access cases. The Fund has adopted a number of policies in the context of the review of facilities regarding the use of charges and maturities. This chapter briefly considers whether it would be appropriate to reconsider some of these issues relating to Fund lending in complex financial crises. The staff would return in a later paper to develop these issues further in light of the views of the Board. 


\section{Box 4. Burden Sharing and Exposure Limits}

The burden-sharing mechanism operates through a symmetrical (downward) adjustment to the rate of remuneration paid by the Fund to creditor members and an (upward) adjustment to the rate of charge applied to outstanding Fund credit so as to generate income for the Fund, replacing the income foregone from unpaid charges by debtor members in protracted arrears to the Fund. The capacity of the burden sharing mechanism to protect the Fund against the loss of income from unpaid charges is limited, because of the floor on the rate of remuneration. ${ }^{1}$ The limit on the amount of unpaid charges that the burden-sharing mechanism can cope with in turn implies a maximum amount of credit exposure by the Fund for which the mechanism can create income for the Fund if charges due on that credit exposure fell into arrears.

The derived maximum exposure to a single borrower from the Fund is directly related to the stock of total Fund credit outstanding since a given income loss from unpaid charges can be more easily absorbed on a larger base of total credit outstanding. The level of the SDR interest rate has only a small impact on the maximum exposure because the rate enters into both the income the Fund derives from charges and the expense of the Fund in paying remuneration.

Under this construct, the exposure limit fluctuates with the level of total credit outstanding. However, it would be preferable to set a maximum exposure limit in nominal SDR terms as this would be transparent and easy to monitor; this would require a judgment about the level of total credit outstanding that is used to calibrate the limit. To capture past fluctuations, one possibility would be to use average credit outstanding for the period 1997-present. Using this level would result in a maximum exposure limit to a single borrower on the order of SDR 12 billion. $^{2}$

A maximum nominal exposure limit would have different implications for the Fund's income position if actual total credit outstanding were different from the average level used to set the limit. At lower levels of total credit outstanding, the potential loss associated with unpaid charges could exceed the capacity of the burden sharing mechanism and would need to be covered by drawing down the Fund's precautionary balances or raising the rate of charge. At higher levels of total outstanding credit, the burden sharing mechanism would not need to be used to its full capacity if unpaid charges were to arise from a borrower with an exposure of up to SDR 12 billion.

${ }^{1}$ The Articles of Agreement (Article V, Section 9) stipulate that the rate of remuneration shall not be less than 80 percent of the SDR interest rate. Under the current burden sharing decision, the Executive Board has decided that the adjustment to the rate of remuneration cannot lower that rate below 85 percent of the SDR interest rate.

${ }^{2}$ This derivation is not affected by income from surcharges since all such income is placed to reserves and is not used to remunerate creditor members or cover the budgetary expenses of the Fund. 
57. The scope for increasing the rate of charge to discourage exceptional access appears limited. It is unlikely that a member facing a capital account crisis would choose not to borrow from the Fund because of a higher rate of charge. Given the high costs of failing to find financing, price-based incentives are likely to be ineffective. On the other hand, higher rates of charge by the Fund are likely to discourage use of Fund resources when the member has other financing options, and a structure of charges is already in place to provide this incentive. The 2000 review of Fund facilities established a framework of increasing surcharges for greater use of Fund resources in the credit tranches and EFF. ${ }^{28}$ Furthermore, the SRF is already subject to a penalty rate of charge, for similar incentive purposes and because of the large risks to the Fund. ${ }^{29}$

58. The appropriate maturity, or mix of maturities, of exceptional access lending needs to be considered. The short maturity of the SRF was chosen consistent with the expectation that a short term financial crisis might be expected to reverse itself quickly. Consistent with this intention, early users of the facility were able to complete repayments on time or ahead of time (Korea and Brazil).

\section{Some capital account crises are unlikely to reverse as quickly as foreseen in the}

SRF, however. More recent experience has shown that in some cases the 1-1 $1 / 2$ year repurchase expectations of the SRF would require repayment at a time when the member's balance of payment situation had not improved. As a result, repurchase expectations under the SRF have been extended or refinanced in Argentina and Turkey, and where problems were expected beforehand, exceptional access has been provided in combination with standby resources (Argentina (2001), Brazil (1998, 2001), Russia (1998), Turkey (2001), and Uruguay (2002)).

60. There are tradeoffs in choosing the appropriate maturity for exceptional access lending. A short maturity may impose a degree of discipline on lending in a type of program that involves high risks to the Fund. By requiring a greater certainty that problems would reverse themselves quickly, it may help to focus Fund lending in cases where there is a greater likelihood that the problem is one of liquidity rather than solvency. On the other hand, experience has shown that the SRF maturity is sometimes too short to be generally

\footnotetext{
${ }^{28}$ Use of credit above 200 percent of quota will carry a surcharge of 100 basis points, and the surcharge will rise to 200 basis points for use of credit above 300 percent of quota. It was agreed at the same time that the surcharges adopted during the review of facilities should not be changed for a period of at least four years. Summing Up by the Acting Chairman, Review of Fund Facilities-Proposed Decisions and Implementation Guidelines, Executive Board Meeting 00/113, November 17, 2000 (Buff/00/175).

${ }^{29}$ Initially 300 basis points above the normal rate of charge, the spread increases to a maximum of 500 basis points depending on how long the purchases are outstanding.
} 
applicable in capital account crises, and somewhat longer maturity lending needs to be available if the Fund is to contribute effectively in some of these cases.

61. Policies on maturity would be implemented through changes to facilities. One option would be to extend the maturity structure of the SRF. For instance, the repurchase expectation could be set at 2-3 years, with a possibility of extension by up to one year. ${ }^{30}$ The high rate of charge would give incentives for members to repay ahead of time where the balance of payments improved faster. Such a maturity is likely to be consistent with a presumption that most Fund financing in capital account crises would be done in the context of an amended SRF. A related option would be to leave the maturity structure of the SRF obligations at $2-2 \frac{1}{2}$ years, but to eliminate the repurchase expectations. This option would also rely on the high rate of charge to provide an incentive for early repurchase where the member's position improved more rapidly.

62. Another option would be to establish policies on mixing. For instance, it would be possible to establish a presumption that SRF resources (on current terms) would be used for any lending when cumulative access exceeds a specified level. ${ }^{31}$ This would be consistent with the notion that higher amounts of access would only be used when there was a greater degree of confidence that the problem was more likely to be resolved in the short term. Such a policy could be done without setting an exceptional access limit, as described above.

\section{The NeXT STEPS AND ISSUES FOR DISCUSSION}

\section{This paper has set out a number of options to strengthen policies on access} during capital account crises. These include an enhanced test of the circumstances under which access above the limits would be considered, based in part on a positive assessment of the debt dynamics using reinforced sustainability analysis. Improvements in the procedures for making exceptional access decisions have also been set out for Board consideration, along with issues relating to the terms and conditions for Fund support. Several other options have been considered to further constrain access, including a presumptive limit on exceptional access, and a firm prudential limit on Fund lending. Based on the Board's views, the staff would expect to prepare a follow-up paper after the Annual Meetings to provide the basis for a decision by the Board.

64. Among their comments, Executive Directors may wish to address the following issues for discussion:

${ }^{30}$ This maturity structure was first proposed in Supplemental Reserve Facility, EBS/97/225, December 5, 1997.

${ }^{31}$ The SRF currently is available to members where expected access would exceed the limits under the credit tranches and EFF. 
- $\quad$ Should criteria for exceptional access be defined to include: (i) the member is experiencing large balance of payments pressures from a capital account crisis, and there are good prospects for (ii) debt sustainability, (iii) an early return to market access, and (iv) success of the program? What role should systemic or contagion concerns play in this context?

- $\quad$ Should the documentation and procedural requirements needed for a request for access above the limits be strengthened to include: (i) raising the burden of proof required in documentation, improving its presentation, and monitoring the access justification guidelines more strictly in the review process; (ii) establishing requirements on the degree and automaticity with which the Board is to be informed about the status of negotiations in potential exceptional access cases; (iii) establishing a stronger presumption of public disclosure; and (iv) requiring an ex post evaluation of exceptional access decisions?

- $\quad$ Should changes to the terms and conditions for exceptional access, and possibly the structure of the SRF and other facilities be considered? Should such changes entail consideration of the appropriate maximum maturity of repayments?

- $\quad$ Should a presumptive limit or norm be established for exceptional access, and prudential limits or ex ante burden sharing be imposed when large access imposes high risks on the Fund? 


\section{The Prague Framework for Private Sector Involvement ${ }^{32}$}

\section{The Committee endorses the report by the Managing Director on the} involvement of the private sector in crisis prevention and management. It welcomes the progress on developing a framework for involving private creditors in the resolution of crises. The Committee notes that this approach strikes a balance between the clarity needed to guide market expectations and the operational flexibility, anchored in clear principles, needed to allow the most effective response in each case. The Committee notes that Fund resources are limited and that extraordinary access should be exceptional; further, neither creditors nor debtors should expect to be protected from adverse outcomes by official action.

\section{The Committee agrees that the operational framework for private sector} involvement must rely as much as possible on market-oriented solutions and voluntary approaches. The approach adopted by the international community should be based on the IMF's assessment of a country's underlying payment capacity and prospects of regaining market access. In some cases, the combination of catalytic official financing and policy adjustment should allow the country to regain full market access quickly. The Committee agrees that reliance on the catalytic approach at high levels of access presumes substantial justification, both in terms of its likely effectiveness and of the risks of alternative approaches. In other cases, emphasis should be placed on encouraging voluntary approaches, as needed, to overcome creditor coordination problems. In yet other cases, the early restoration of full market access on terms consistent with medium-term external sustainability may be judged to be unrealistic, and a broader spectrum of actions by private creditors, including comprehensive debt restructuring, may be warranted to provide for an adequately financed program and a viable medium-term payments profile. This includes the possibility that, in certain extreme cases, a temporary payments suspension or standstill may be unavoidable. The Fund should continue to be prepared to provide financial support to a member's adjustment program despite arrears to private creditors, provided the country is seeking to work cooperatively and in good faith with its private creditors and is meeting other program requirements. The Committee urges progress in the application of the framework agreed in April 2000, and in further work to refine the analytical basis for the required judgments, and it looks forward to a progress report by its next meeting.

${ }^{32}$ Paragraphs excerpted from the Communique of the International Monetary and Financial Committee of the Board of Governors of the International Monetary Fund, September 24, 2000. 


\section{An Overview of Past Exceptional AcCess Programs}

67. This annex considers experience with past exceptional access cases, to provide a factual basis for consideration of possible changes in access policy. The cases examined are Mexico (1995), Thailand (1997), Indonesia (1997-2000), Korea (1997), Russia (1998), Brazil (1998), Turkey (2000-2001) and Argentina (2001). These eight cases constitute most of the Fund arrangements during the period 1995-2001 where the Fund invoked exceptional circumstances and/or total access substantially exceeded normal limits. ${ }^{33}$

\section{A. The Amount of Fund Support in the Exceptional Access Cases}

68. Measured in terms of quota, the Fund lent more in these exceptional access cases than it has in any previous arrangements in its history. As shown in Table 1, cumulative access in most of the cases has been in the range of 500-700 percent of quota. For Korea (1,938 percent of quota), and recently for Argentina (800 percent) and Turkey (1,560 percent), access was even higher. These numbers are slightly distorted by the fact that the arrangements approved in 1997 and 1998 preceded the $11^{\text {th }}$ Review quota increase, and by the fact that in some cases, actual quotas diverge significantly from calculated quotas. Nevertheless, the recent cases represent an unprecedented use of Fund resources in terms of quota. $^{34}$

69. Access was heavily frontloaded in the exceptional access cases, especially when SRF resources were used. The length of arrangements varied between 18 and 36 months, with an average of $2 \frac{1 / 2}{2}$ years. Despite this, over 70 percent of total access was made available in the first year of each high-access arrangement, and in some cases over 90 percent of total access was made available in the first year. Other GRA programs tend to be more evenly phased, as illustrated by non-exceptional arrangements approved from May 2001 to May 2002, which averaged 22 months in length and made 53 percent of total access available in the first year.

${ }^{33}$ In Turkey (1999), exceptional circumstances were invoked but access beyond the limits was not substantial. The case of Brazil (2001) is excluded; the authorities did not intend to draw at the outset.

${ }^{34}$ An earlier case was Turkey (1980) with cumulative access of 625 percent of quota (at a time when the cumulative access limit was 465 percent of quota). Apart from this, and before the exceptional access cases, the highest cumulative access granted had been in the early 1980s, following the oil crisis and immediately before a large quota increase. In 1983 there were four cases in excess of 500 percent of quota, the highest being Jamaica (553 percent of quota), and the others being Turkey, Côte d'Ivoire and Korea. These occurred after approval of the $8^{\text {th }}$ quota increase in March 1983, but before its effectiveness in November 1983. Since the mid-1980s the highest cumulative access approved had been 411 percent of quota for Mexico in 1990 in the context of a debt reduction operation under the Brady Plan. 
70. Reflecting the size of their economies, Fund support for individual countries was also very substantial measured in SDRs, and most cases accounted for a substantial share of the Fund's outstanding and total usable resources at that time. In most of the exceptional access cases Fund support has been within the range of 12 billion SDRs to 17 billion SDRs. ${ }^{35}$ In five of the eight cases the arrangement exceeded 15 percent of the Fund's usable resources at the time (Figure 1). In seven cases the Fund's commitment amounted to more than 15 percent of Fund resources then outstanding (Figure 2). In one case (Russia), the risks to the Fund were explicitly noted.

71. Access was also high in relation to the countries' GDP, although this metric indicates a different ordering of exceptional access cases. This is an important indicator in part because it is the one most often used to measure the extent of adjustment in the countries, and in part because in some of the countries, notably the highest access cases of Korea and Turkey, the countries' quotas at the time of the arrangement were unusually small in relation to GDP. For example, quota was only 0.2 percent of GDP in the case of Korea in 1998, and annual access was 1.5 percent of GDP. Total access in most of the exceptional access cases was in the range of 2-5 percent of GDP, but access was higher in Turkey (10 percent, despite a relatively low quota in terms of GDP) and Argentina ( 8 percent). For comparison, median total access in cases within the access limits is less than 1.5 percent of GDP, but in five other (non-exceptional access) cases since 1993 Fund access has been at or in excess of 5 percent of GDP. ${ }^{36}$

${ }^{35}$ This is true in every case except Thailand and Indonesia, where access was lower. In Turkey the access approved in the 2001 augmentation was 15 billion SDRs. Total access outstanding under the revised SBA approved in 2002 would peak at 18 billion SDRs in 2004 if all purchases were made on schedule.

${ }^{36}$ These were Gabon 1995 (5.4 percent), Ukraine 1995 (5.0 percent) Moldova 1996 (8.2 percent), Bulgaria 1998 (7.1 percent) and Ukraine 1998 (5.5 percent). 
Figure 1. Fund Arrangements 1/

(In percent of usable Fund resources)

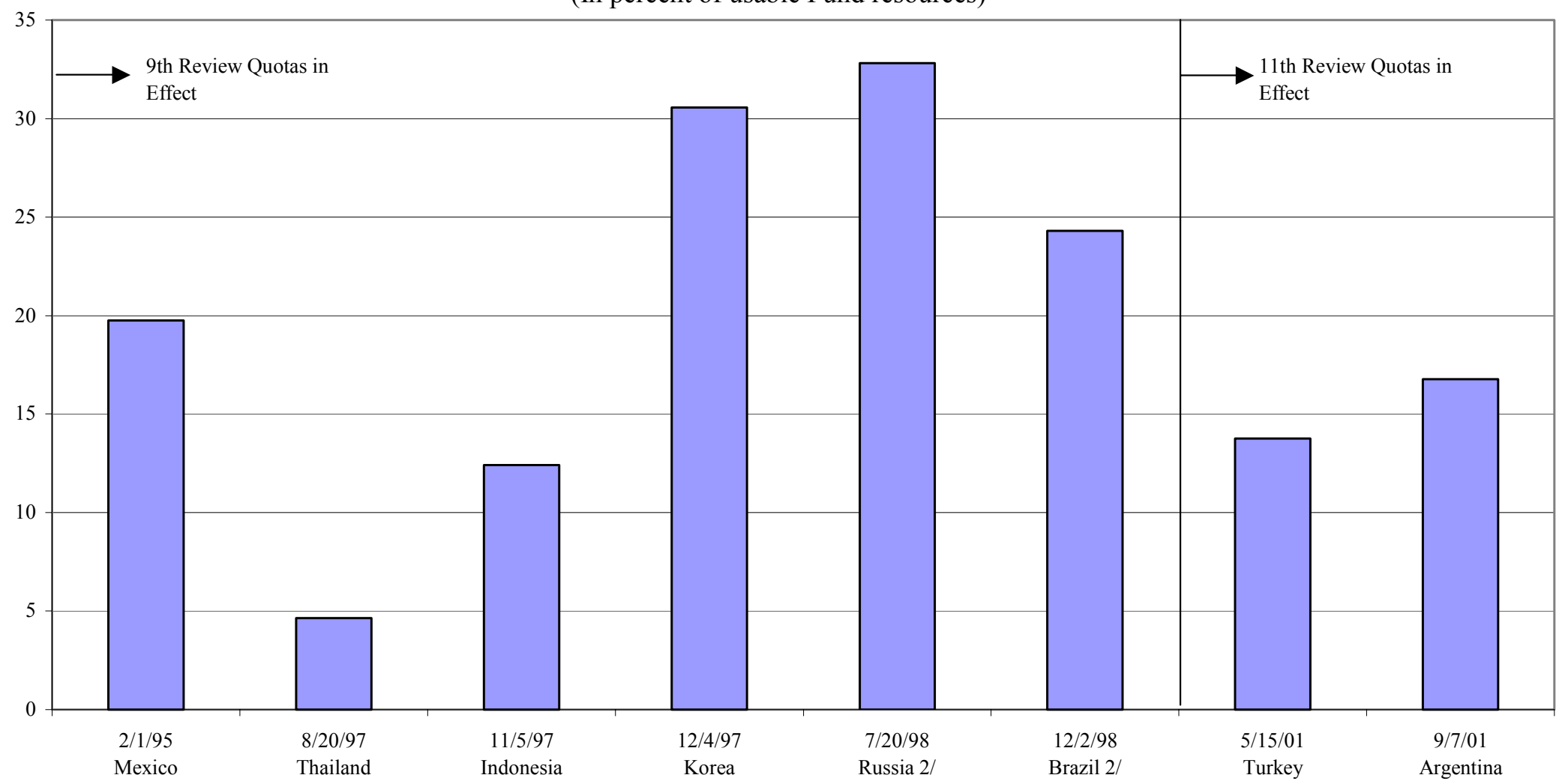

Source: IMF Treasurers Department Data and staff calculations.

1/ All cases are in percent of usable resources at the end of the month in which the arrangement was approved or augmented with certain exceptions.

Russia uses usable resources at end-October 1998. Thailand is in percent of usable resources at end-October 1997, and Mexico is in percent of usable resources at end-1996.

2/ In the case of Russia and Brazil, usable resources include GAB/NAB resources activated. SDR 6.3 billion was activated under the GAB for Russia and

SDR 2.9 billion under the NAB for Brazil. 
Figure 2. Fund Commitments

(In percent of total Fund credit outstanding) 1/

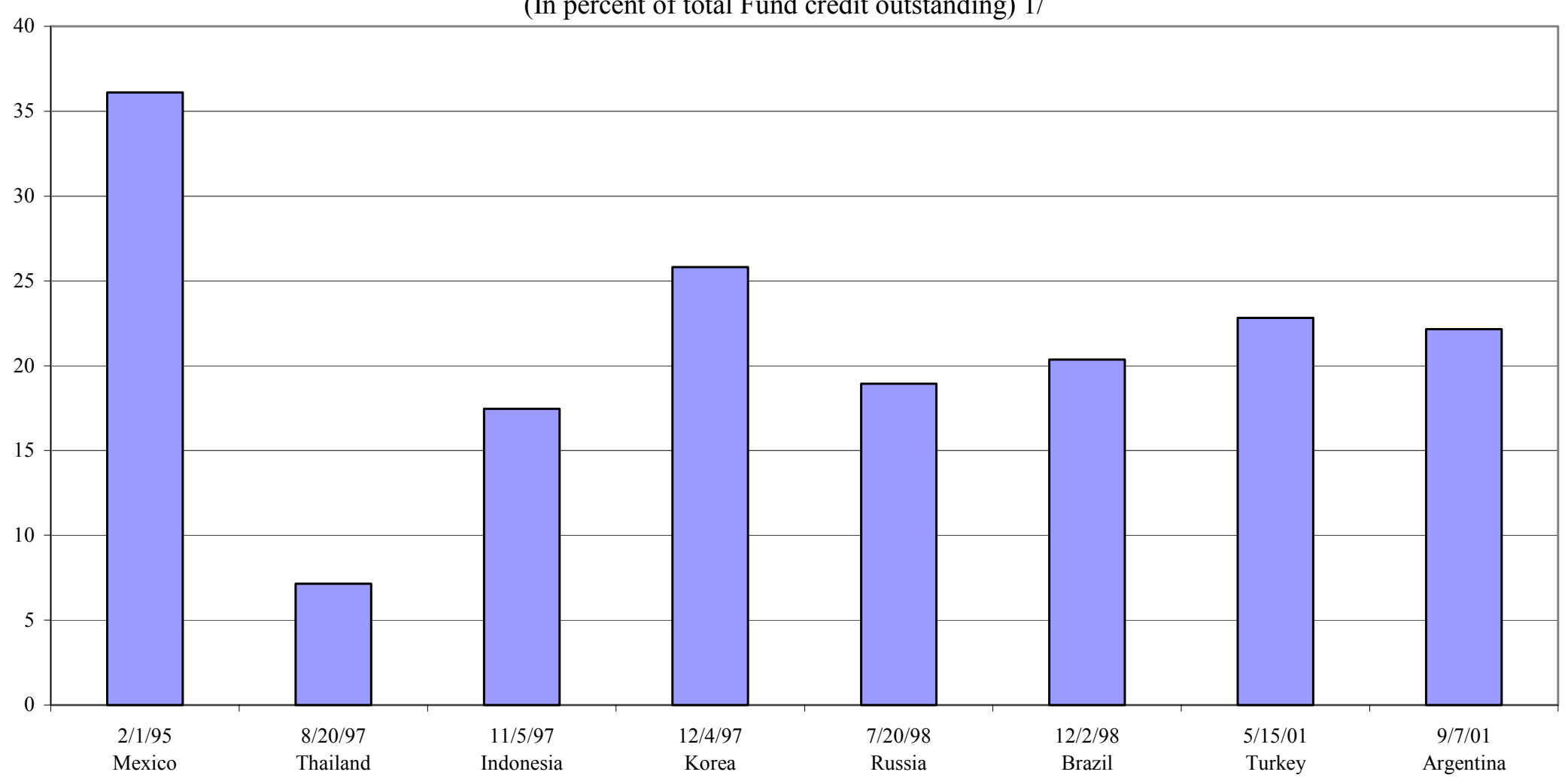

Source: IMF Treasurers Department Data and staff calculations.

1/ Commitment in each arrangement equal to approved amount in cases of new arrangements, or augmentation plus previously undrawn amounts in the cases of augmentations. Fund credit outstanding is the total Fund credit outstanding at the end of the month preceeding the approval or augmentation. 
72. In the early exceptional access arrangements, Fund support was supplemented with commitments from other multilateral and official bilateral creditors; more recently this has fallen away. In Mexico, Thailand, Indonesia, Korea, and Brazil substantial commitments were made by official bilateral creditors, and if all such commitments were included the official financing package as a share of GDP was significantly higher, ranging from 5 percent of GDP in the case of Brazil to 9 percent of GDP in Mexico. ${ }^{37}$ Since the quota increase of 1998, bilateral contributions have more or less ceased, and the Fund share of total official financing has greatly increased (Figure 3). For example, in Mexico Fund access was 37 percent of the total package, but it was close to 100 percent of the Argentina and Turkey packages.

73. Despite being very high in relation to past practice, access to Fund resources has still only covered part of the ex post adjustment for the exceptional access countries. In the seven exceptional access cases in the 1990's, Fund disbursements averaged only one-third of the total adjustment in the goods and services balance. The change in the goods and services balance in the two years following the crisis was over 10 percent of GDP in most countries (Figure 4), reflecting the dominance of the capital movements in the crises.

74. Fund support was also significantly lower than total ex ante potential balance of payments need, although higher than in non-exceptional access arrangements. Total Fund support covered only a portion of the projected gross external financing needs of the country, from a low of six percent in Thailand and 13 percent in Brazil and 15 percent in Korea, to 26 percent in Mexico, between 34 and 39 percent in Indonesia, Turkey and Argentina, and at the high end, to 42 percent in Russia (Table 1). Fund access in the crisis cases also amounted to less than a third of M2 in all these cases. Moreover, Fund access amounted to less than a third of short-term external debt (for the entire country, not just the sovereign) in all cases except Russia and Argentina.

\section{B. Some Outcomes of Exceptional Access Programs}

\section{The attainment of external viability}

75. Measured by the simplest indicator of viability, capacity to repay the Fund without strain, most of the exceptional access cases have been successes. In most cases, the borrowing country was able to repay the Fund either on schedule or in advance of scheduled dates. Mexico, Brazil, and Korea all made advance repurchases of SBA resources.

\footnotetext{
${ }^{37}$ Not all bilateral commitments were actually disbursed. For example, in Indonesia and Korea some funds pledged by bilateral creditors formed a "second line of defense" but were not subject to well-defined terms and conditions and were never disbursed. For details see IMF-Supported Program in Indonesia, Korea and Thailand: A Preliminary Assessment, IMF Occasional Paper No. 178, June 1999.
} 
Figure 3. Composition of Financing Packages in High Access Cases

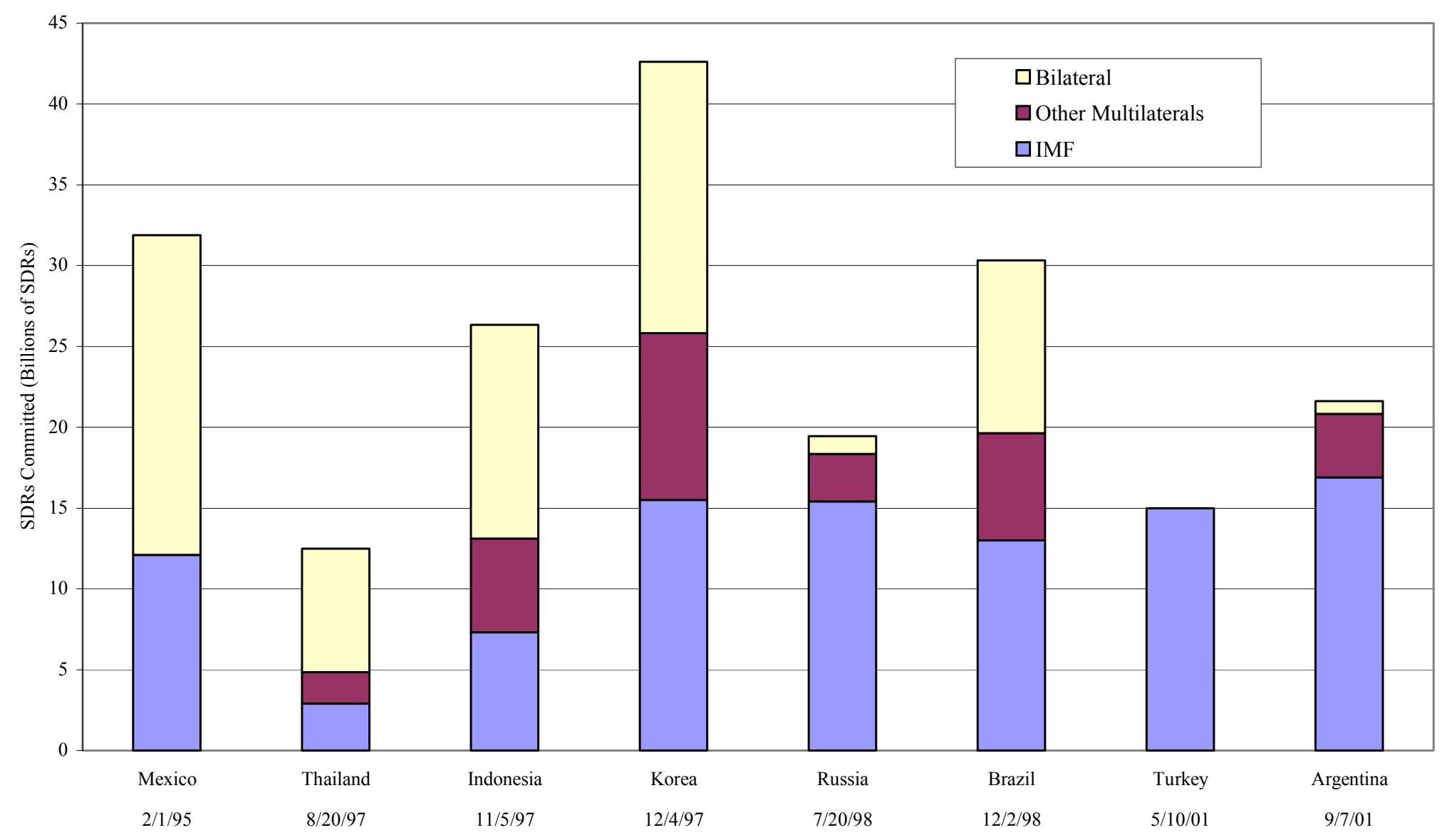

Source: IMF Board documents and staff calculations. 
Figure 4. Distribution of Adjustment

(In percent of GDP) $1 /$

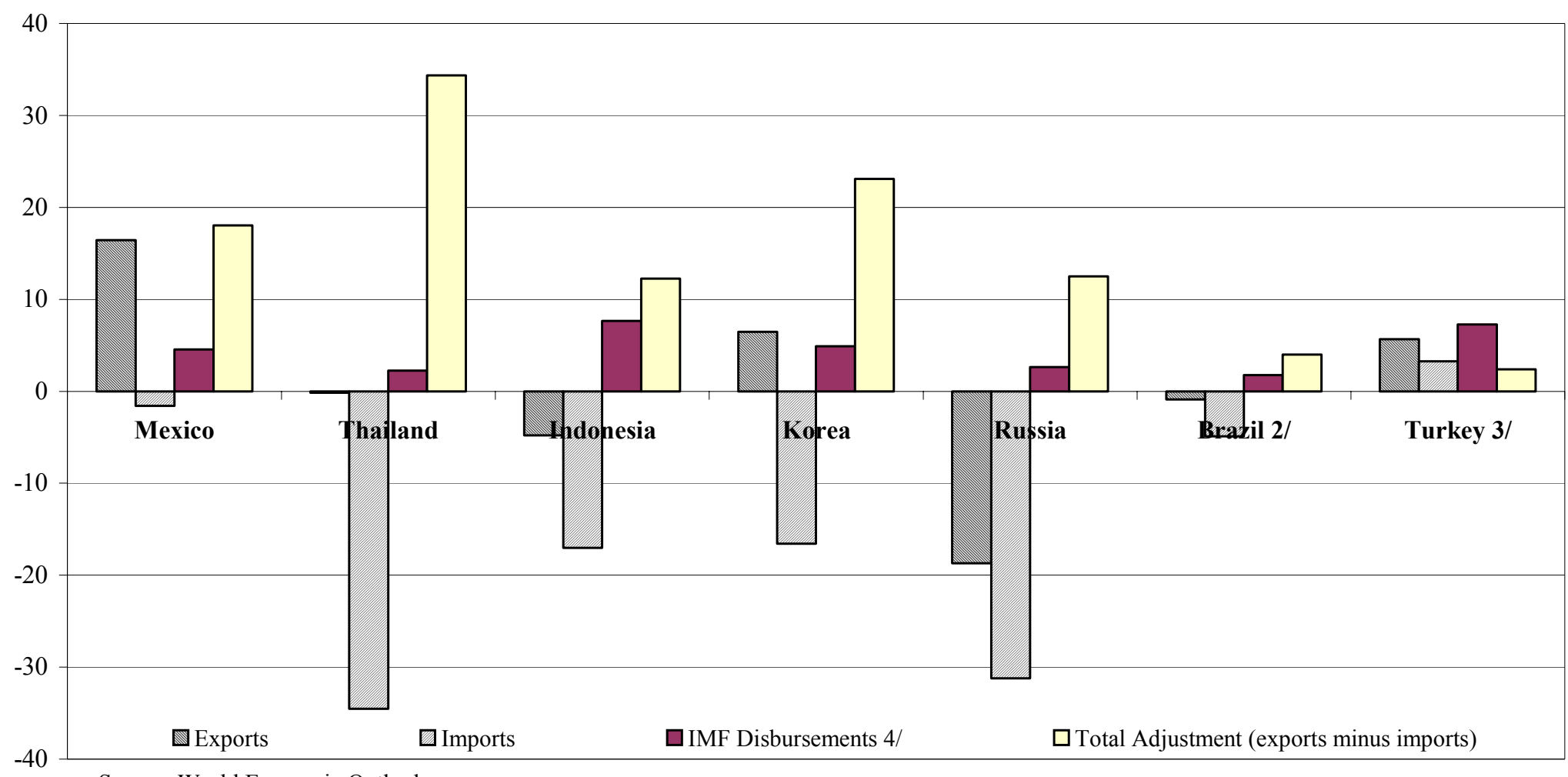

Source: World Economic Outlook.

1/ Cumulative adjustment during crisis year $(\mathrm{T})$ and following year $(\mathrm{T}+1)$.

2/ 1998-2000 (includes 3 years, as the program was approved at end-1998).

$3 / 2001$ only (excludes 2000, which is the crisis year).

4/ Includes augmentations or new arrangements after the initial arrangement, but excludes undrawn amounts. 
Similarly, all countries except Argentina have repurchased SRF resources on or in advance of "expectations."

76. However, in some cases augmentations of access have been needed, and higher access has sometimes been used, in effect, to refinance outstanding obligations to the Fund. Indonesia and Turkey repurchased Fund resources on or in advance of the expected dates, but received new support from the Fund at the same time. Argentina, Indonesia and Turkey had also received augmentations, accompanied by a substantial change in the macroeconomic program of their access in the original arrangement. Still, in the other five of the eight cases no augmentation proved necessary, and the Fund was repaid early or on time. $^{38}$

77. In the six countries that the Fund supported through exceptional access arrangements in the 1990s (on which outcomes are better known) vulnerabilities are generally significantly lower than prior to the crises.

- Adjustment has strengthened the positions of all of these countries. Most of the crisis countries now have external current account surpluses, reflecting an improvement in competitiveness, and reduced use of external financing (Figure 5). Most of them also have stronger primary fiscal surpluses, although overall fiscal deficits are often higher because of higher debt-servicing costs. Finally, most have made substantial progress on their agenda of structural reforms, especially in the banking sector. All of the eight crisis countries now have floating exchange rates.

- Economic recovery is well under way in most of the countries. In four of the six countries (Brazil, Korea, Mexico and Russia) that experienced crises prior to 2000-01, real GDP is now above pre-crisis levels. GDP fell substantially in many countries (over 10 percent in Indonesia and Thailand, which have not regained pre-crisis levels of GDP) but most countries have experienced strong growth since.

- Inflation is under control in all of the 1990's crisis countries. Inflation increased in all countries in the crisis year or the following year, but has since fallen back.

- $\quad$ Adjustment required a sharp real depreciation of currencies at first, and they remain on average 20 percent lower after four years. Real effective exchange rates declined on average by 30 percent in the first year after the crisis, and recovered to about 80 percent of pre-crisis levels after four years.

${ }^{38}$ In Korea, access was rephased to allow a larger early drawing, but was not augmented. 
Figure 5. High Access Cases: Selected Indicators (In percent of GDP)

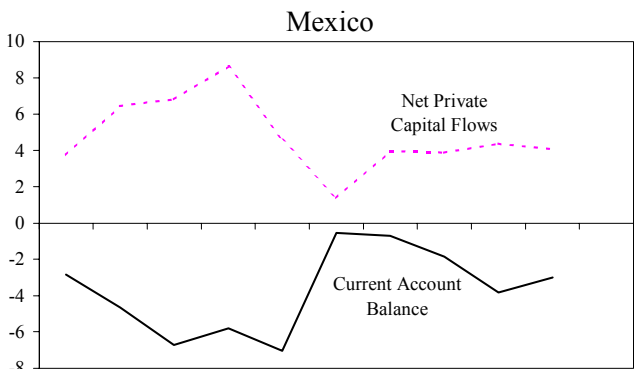

$\begin{array}{lllllllllll}1990 & 1991 & 1992 & 1993 & 1994 & 1995 & 1996 & 1997 & 1998 & 1999 & 2000\end{array}$
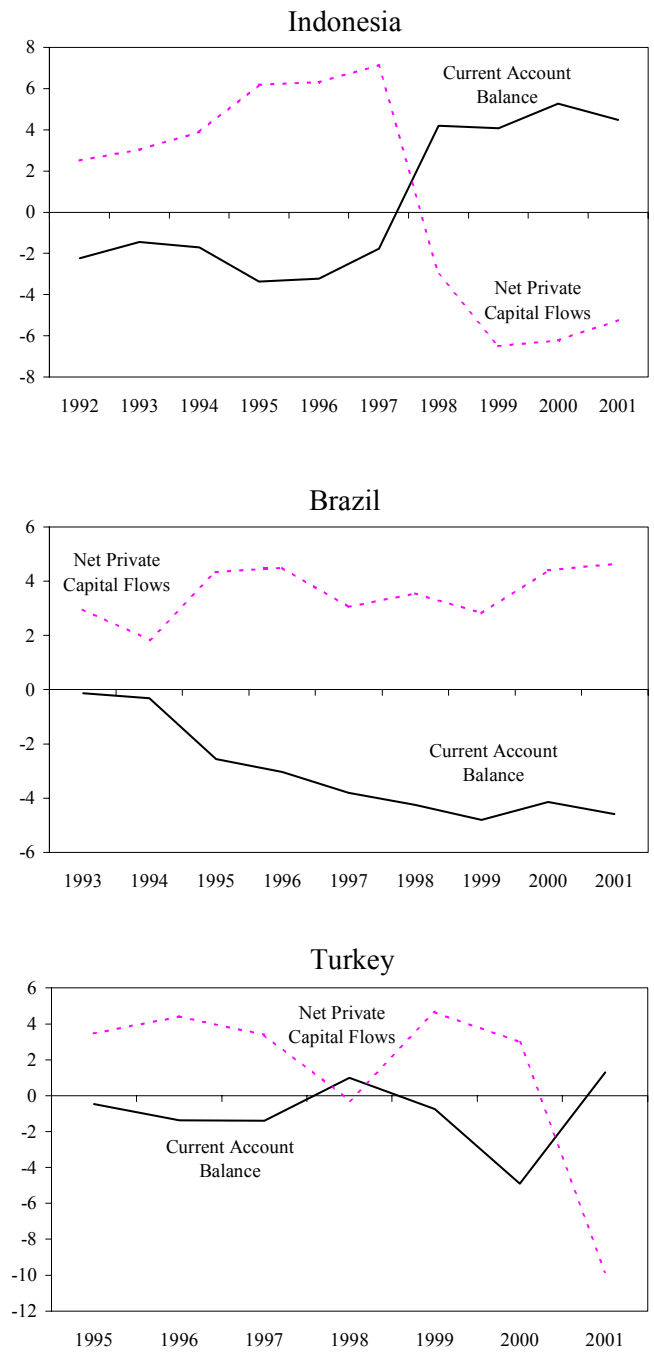

Source: WEO data and staff calculations.
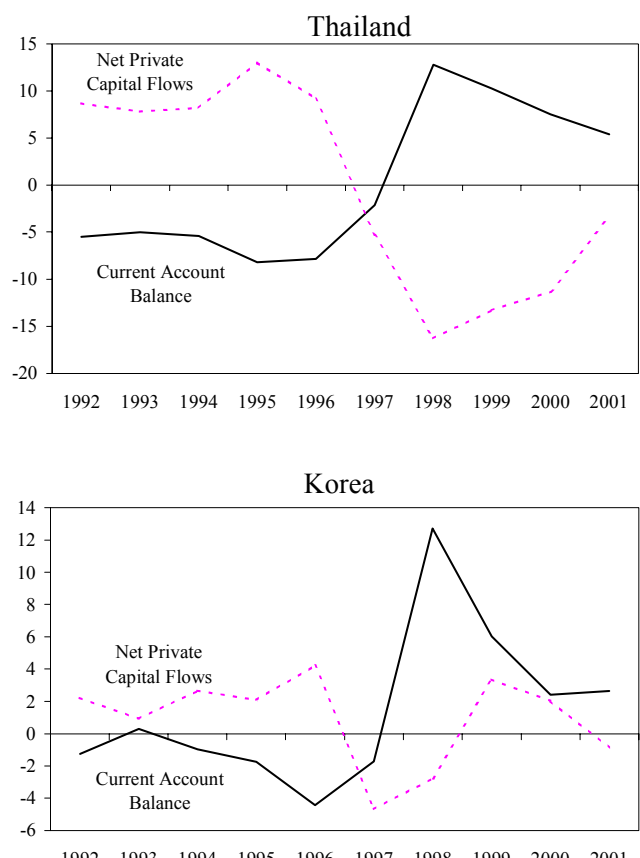

$\begin{array}{llllllllll}1992 & 1993 & 1994 & 1995 & 1996 & 1997 & 1998 & 1999 & 2000 & 2001\end{array}$
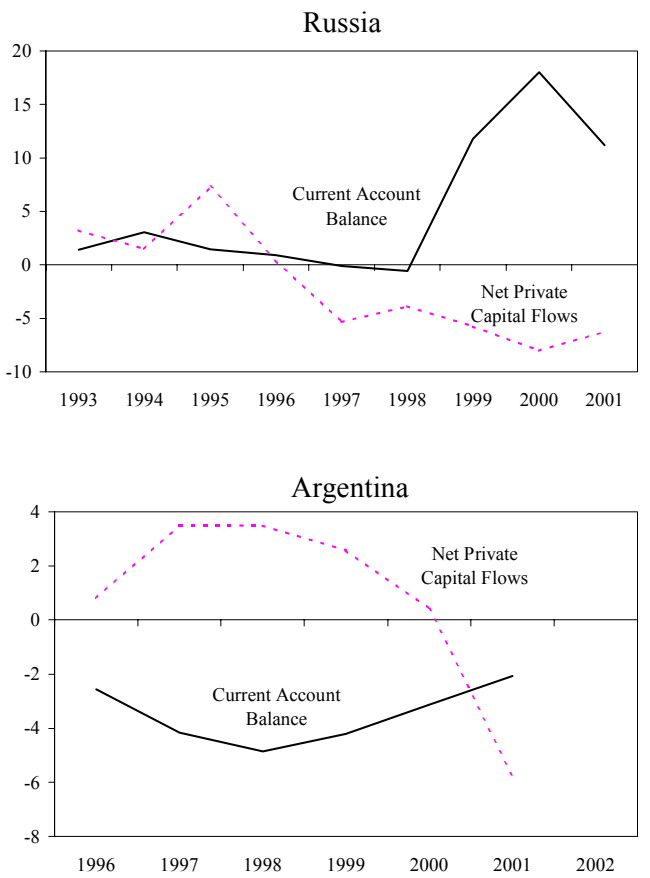
- $\quad$ Portfolio investment has declined, but foreign direct investment is higher. Therefore, overall inflows of foreign financing have shifted to a more stable footing, leaving the countries less vulnerable than before.

- The exceptional access countries have also built up reserves substantially, suggesting that they are willing to make temporary sacrifices to insure against another crisis. Reserves have increased both in dollar terms (Figure 6) and in terms of coverage of short-term debt in almost all countries.

78. Nevertheless, significant vulnerabilities remain in some countries, and others are still in the throes of crisis. In most of the countries that experienced crises in the $1990 \mathrm{~s}$ external debt as a share of GDP is somewhat higher than before the crisis (Figure 6). In some countries this makes for significant vulnerability: external debt in Indonesia is close to 100 percent of GDP, almost twice the pre-crisis level, and Brazil's external debt to GDP ratio has risen from 25 percent to 42 percent since the crisis, despite expectations that it would fall or at least stabilize. ${ }^{39}$ In the case of Turkey, substantial adjustment has already taken place, but the outcome in terms of sustainability is not yet certain. In the case of Argentina, the work of rebuilding after the collapse has only just begun.

\section{Securing capital market financing}

79. Capital outflows stopped, but they lasted longer and were larger than expected. The rationale for high Fund support in cases where balance of payments pressures arise from capital outflows is not to finance these outflows but to stem them. In most of the crisis countries the program and accompanying exceptional access did not initially stem or reverse capital outflows. The capital account balance was, in most cases, significantly worse than projected in the first year of the Fund's involvement. Projection errors ranged from $3 \frac{1}{2}-5$ percent of GDP in Mexico and Brazil to 9-17 percent of GDP in the Asian crisis countries.

80. Most of the affected countries have renewed access to market financing, but flows are smaller and terms are stiffer than before. Most countries were able to issue bonds, debt or equity soon after the crisis (Figure 7), although as noted above the issues were not sufficient to compensate for other capital outflows. Those countries that have regained capital market access face spreads that are generally still above pre-crisis levels (Figure 8). Most of the crisis countries (except Brazil and Mexico) have not accessed large amounts of

${ }^{39}$ In most countries, there has also been a rise in public debt as a share of GDP. However, in some cases, the rise in the ratios primarily reflects the public sector taking on the responsibilities of failed banks (and by extension corporations), and, since their financial position was precarious before the crisis - and indeed led to the crisis in some countries - the rise in the public debt constitutes recognition of already existing problems rather than an intensification of problems. 
Figure 6. High Access Cases: Selected Indicators

(Left-axis: Debt in percent of GDP; Right-axis: Gross international reserves in billions of U.S. dollars)
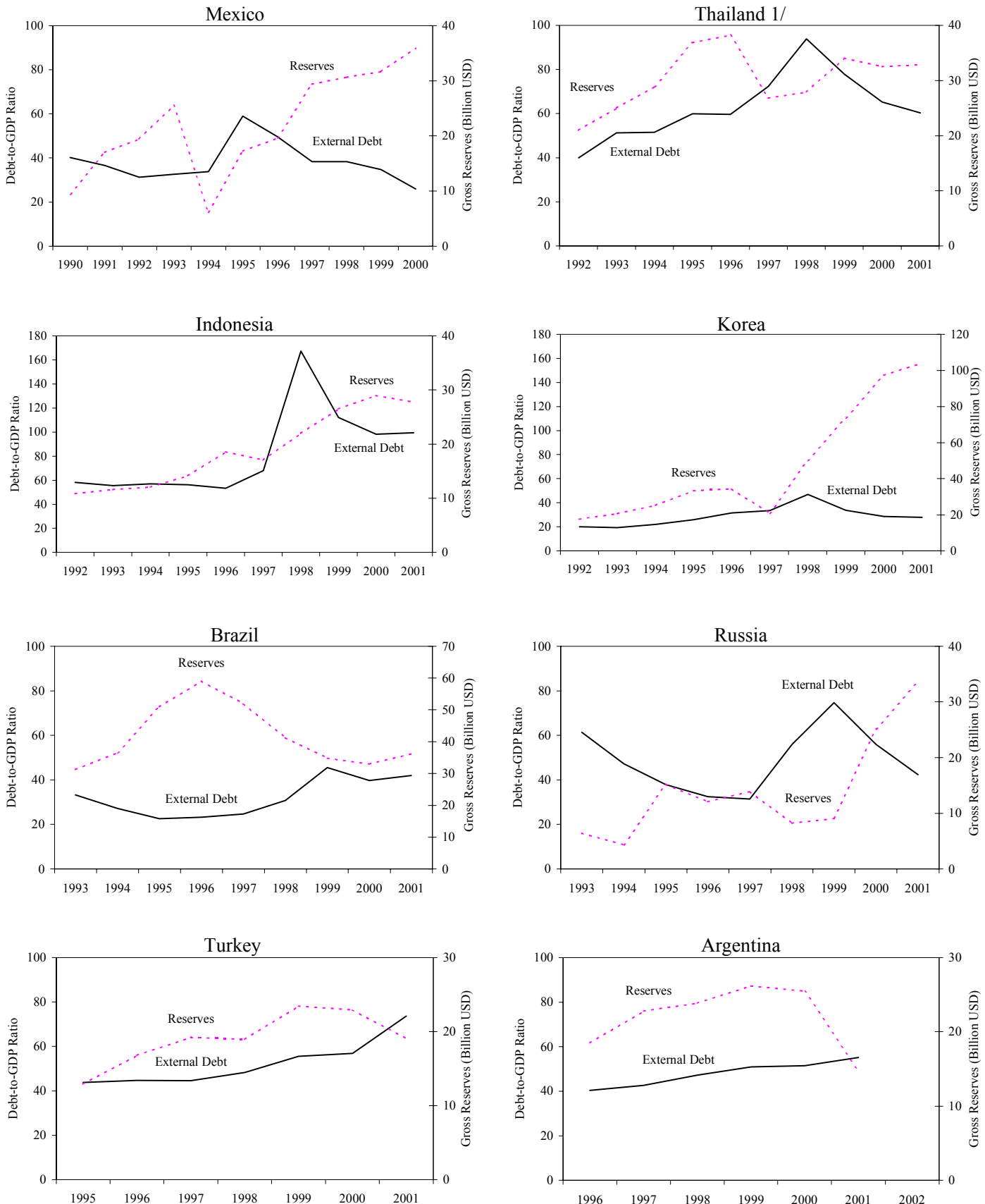

Source: WEO data and staff calculations.

1/ If the swap/forward position is taken into account, net reserves had dropped to $\$ 0.4$ billion in September 1997. 
Figure 7. Market Access Indicator for Selected High Access Cases 1/

(In millions of US\$)
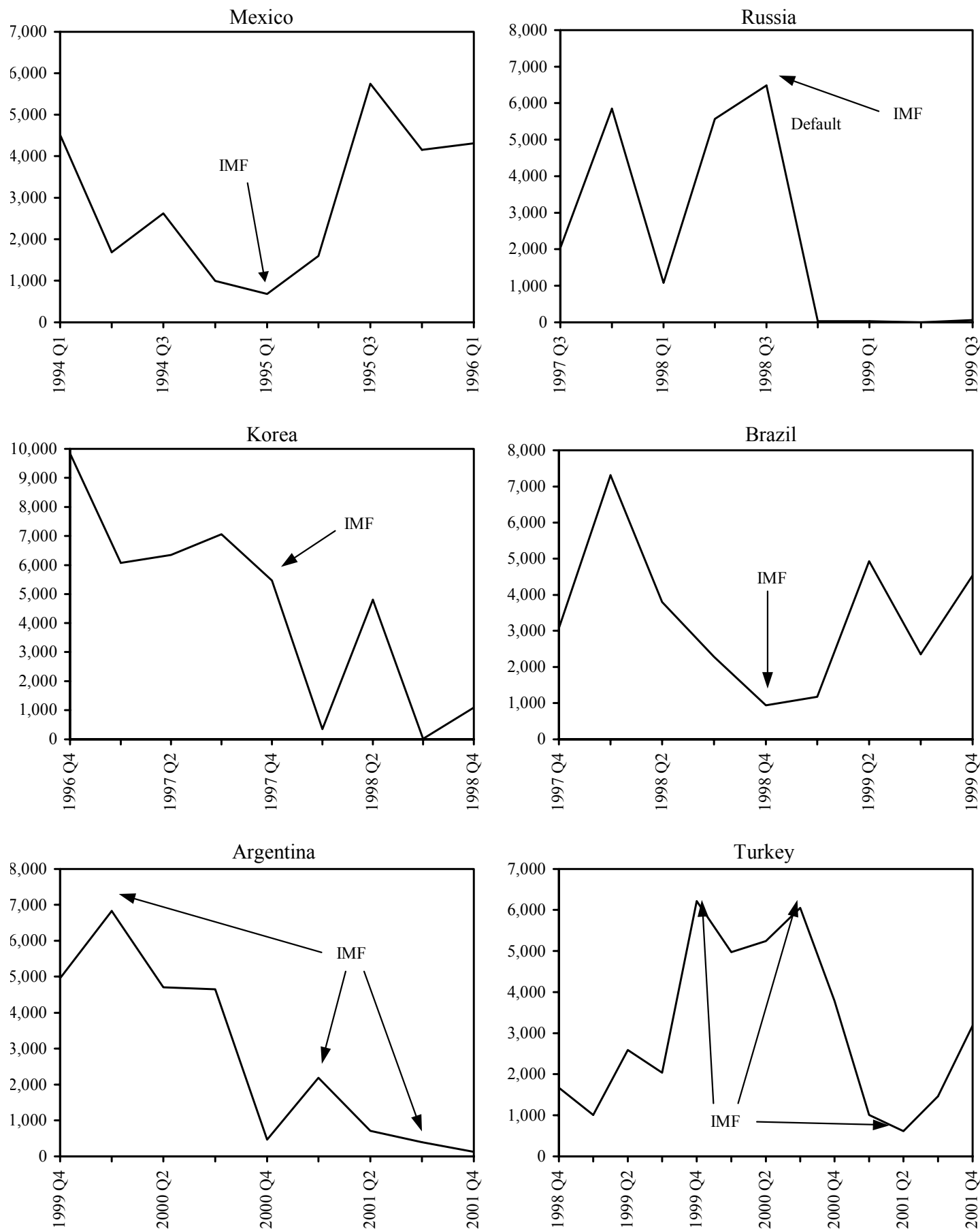

Source: Capital Data.

1/ Calculations based on gross issuance of bonds, loans and equities. 
Figure 8. Market Spreads Before and After IMF Arrangements for Selected High Access Cases
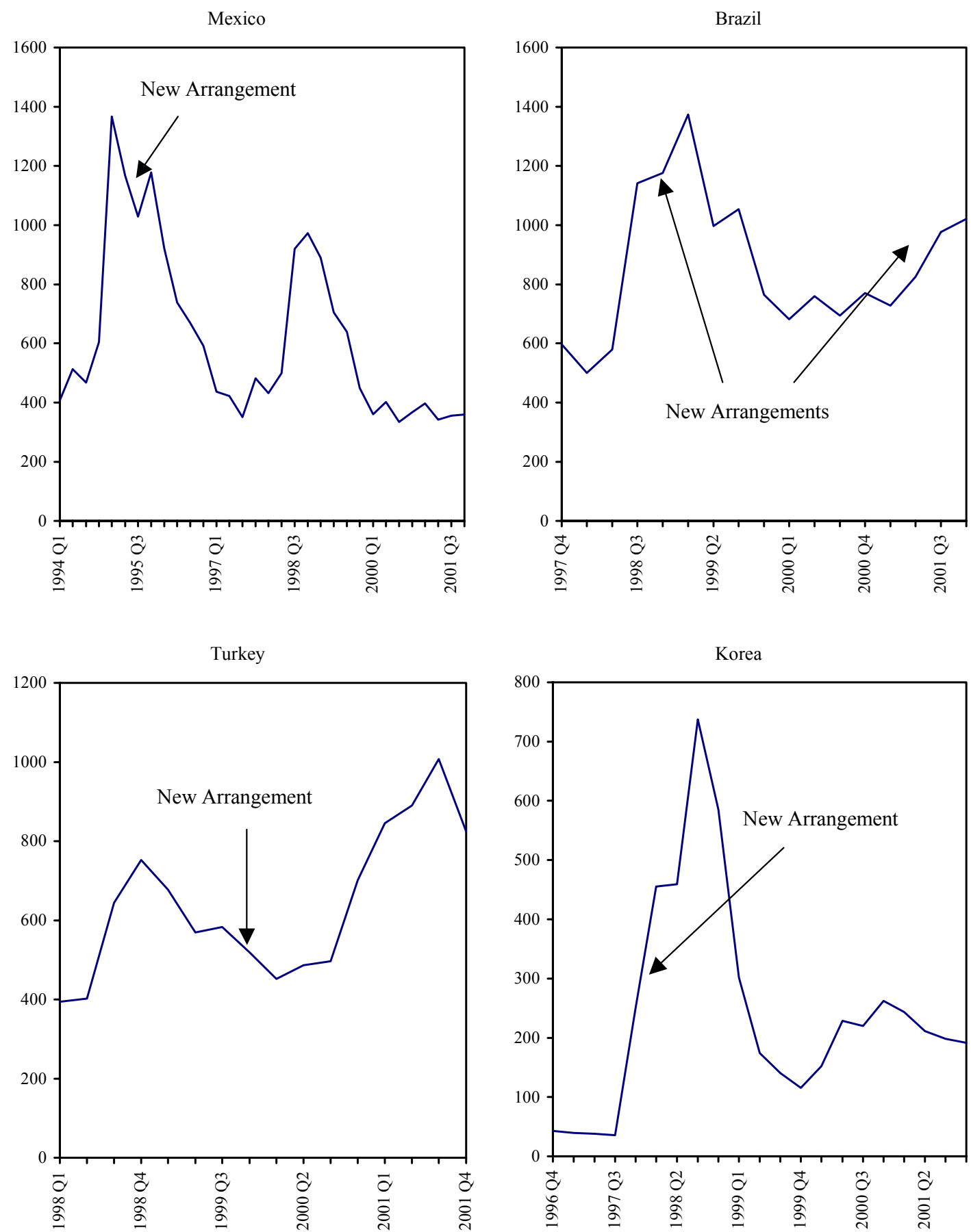

Source: Capital Data; and staff calculations. 
private capital since the crisis. A number of supply and demand factors are likely to be contributing, including more conservative macroeconomic management and a trend toward lower capital flows to emerging markets in general (Figure 5). Since 1997, emerging markets have seen sustained and substantial withdrawals of debt finance on a net basis. ${ }^{40}$

81. The caution of private creditors in extending new financing recently may reflect the fact that they did not come out of the crises completely unscathed. In particular, two cases have ended in default by the sovereign (Russia and Argentina) with a comprehensive restructuring and reduction of debt held by private creditors (still in prospect in Argentina). In other countries (notably Indonesia) some private creditors defaulted, but the sovereign did not default or comprehensively restructure its debt. In Korea and Indonesia, a maturity-extending rescheduling of interbank debts helped provide financing during the program period. In both cases, the rescheduled bank debt benefited from an explicit government guarantee. In Korea, this rescheduling was central to the ultimate success of the program.

\section{Has exceptional access under Fund arrangements added to moral hazard?}

82. Since one of the roles of the IMF is to limit the adverse consequences of crisis for its members, some degree of moral hazard is inevitable. IMF programs seek to contain the economic costs of financial crises, and to the extent that they are successful, members and other affected parties are likely to be more relaxed about the risk of a crisis than they would otherwise have been. The question is whether there is evidence that the additional moral hazard created by the IMF's interventions in the exceptional access cases was so large that it outweighed the benefits of that support to the Fund's members. The answer is that this seems unlikely to have been the case.

83. Developments in financial markets since 1994 do not support the view that the advent of exceptionally large financial packages has significantly increased creditor moral hazard in the system. ${ }^{41}$ Despite Fund support on an unprecedented scale, private

${ }^{40}$ Net private capital flows to developing countries in 1996 amounted to US\$192 billion, declining to US\$33 billion in 1999 and US\$29 billion in 2001 (WEO, Winter 2002 Vintage).

${ }^{41}$ Lane and Phillips argue that "in the vast majority of instances, events that would plausibly have sent signals to markets regarding the availability and magnitude of IMF financing did not have the effects predicted under the hypothesis that moral hazard is important" and that "the role of moral hazard in recent crises may have been seriously overstated by some observers." Does IMF Financing Result in Moral Hazard, IMF Working Paper No. 00/168, October 2000. In contrast, dell'Ariccia, Gödde and Zettelmeyer find that prior to mid-1998, there was a compression of spreads that is consistent with moral hazard during the period between the Mexican and the Russian crises; however, there is no evidence of moral hazard after the Russian crisis, Moral Hazard and International Crisis Lending: A Test, draft, November 2000. 
creditors appear to be more concerned about the risk of default than they were before the crises:

- Across emerging market borrowers, spreads on foreign exchange-denominated debt are substantially higher than before the Mexican crisis, and at the end of 2001 remained so even for countries which appear to have weathered their crisis well. They also remain at levels that imply recognition of a default risk significantly higher than historical averages.

- Bond spreads have also been more dispersed across countries, suggesting that investors perceive substantial differences in actual risk despite the potential availability of large-scale official support. The cases of default have illustrated that Fund financial support, even when large in comparison with the past, cannot insulate investors from the effects of serious policy failures in our member countries.

84. It may be that at points during the last several years creditors were more reassured than they should have been by the Fund's involvement. The potential availability of Fund support clearly played some role in providing what proved to be false comfort to investors in Russia prior to August 1998. The Fund's involvement in Argentina throughout the latter half of the 1990's may have made investors more willing to finance the buildup of what became an unsustainable debt burden than they otherwise would have been willing to do, and it clearly delayed the onset of default through the course of 2001.

\section{However, the defaults in Argentina and especially Russia must have had a} chastening effect on creditors. After the Russia default it is not plausible to believe that there is any emerging market that is seen as too big to fail. The Fund's extensive involvement in Argentina provides further evidence that there are times when the Fund can only postpone a default.

86. There is also little evidence of greater debtor moral hazard arising from the exceptional access given by the Fund. Even high Fund access and additional multilateral and bilateral support was not sufficient to prevent the need for adjustment — adjustment which has been very costly to the economies involved. Debtors' desire to avoid a repeat of this is reflected in the massive build up of reserves in the years following the crises in most of the countries concerned. ${ }^{42}$

${ }^{42}$ Indeed, if debtor moral hazard was a serious problem, there is more evidence of it before the capital account crises than after them. All eight exceptional access cases had used Fund resources previously, though in the Asian countries the last Fund arrangement had been more than a decade before. Some countries had arrangements in place already when the crisis hit. Brazil and Mexico last had Fund arrangements in the early 1990s. Argentina, Russia and Turkey all had arrangements at the time of the crisis. Arguably, the severity of the crises has 
87. There is also no evidence of a greatly increased demand for Fund resources following the precedent of the capital account crisis cases. The advent of exceptionally large programs was not followed by a generalized increase in access under GRA programs in relation to quota, though the quota implemented in January 1999 made substantially greater resources available within normal access limits. Access under GRA programs has remained at 41 percent of quota on average, roughly the same level of the pre-Mexico crisis era.

made the members concerned both more conscious of specific risks and more risk averse than they were before the crisis, hence the build up of reserves. 


\section{Sustainability Analysis of Past exceptional Access Programs}

88. Only two initial program documents of the eight exceptional access cases contained sensitivity analyses of the medium-term projections. The main risks to the programs were viewed in terms of dichotomous events, such as rollover or no rollover of short-term debt. The consequences of such events on key sustainability indicators, however, were not examined in detail. Applying a systematic sensitivity analysis at the time of program approval could have illustrated the risks in a more comprehensive way and might have led to a reassessment of vulnerabilities.

89. A modified sustainability framework, including a standardized sensitivity analysis, has been developed recently. ${ }^{43}$ The sensitivity analysis comprises six basic tests and two composite tests. The basic tests assess the impact on the external debt-to-GDP ratio of (i) interest rates, GDP growth, U.S. dollar GDP deflator, and non-interest current account balance at the average of the ten years preceding the crisis rather than the forecasted levels, (ii) a one-off depreciation of the exchange rate by 30 percent, and changes by two standard deviations from the average of the ten years preceding the crisis of (iii) interest rates, (iv) GDP growth, (v) U.S. dollar GDP deflator, and (vi) the non-interest current account balance. The composite tests apply a combination of one-standard deviation shocks, and country-specific standard deviation shocks.

90. A retrospective sensitivity analysis undertaken for six out of the eight cases is illustrated in Figure 9. ${ }^{44}$ The charts show the baseline program projections for the external debt-to-GDP ratio, actual outcomes, and the range of possible outcomes indicated by a sensitivity analysis. The most significant risks stemmed from sharp depreciations of currencies (only in the case of Mexico was the main risk a negative shock to the current account). In most cases, these were not anticipated to the extent they actually occurred, and impaired the containment of external debt-to-GDP ratios.

${ }^{43}$ See Assessing Sustainability, SM/02/166, May 28, 2002.

${ }^{44}$ In the cases of Argentina and Turkey, the analysis refers to 1999 instead of the actual crisis year, since these countries already had programs at that time and to allow for a three-year horizon of projections.

${ }^{45}$ Not all tests were conducted, since the country-type specific standard deviations have yet to be developed. Also, to determine the pre-crisis averages, instead of a ten-year period preceding the crisis, a five-year period was selected. 
Figure 9. Sensitivity Analysis for External Debt-to-GDP Ratio (Time of Program Approval)
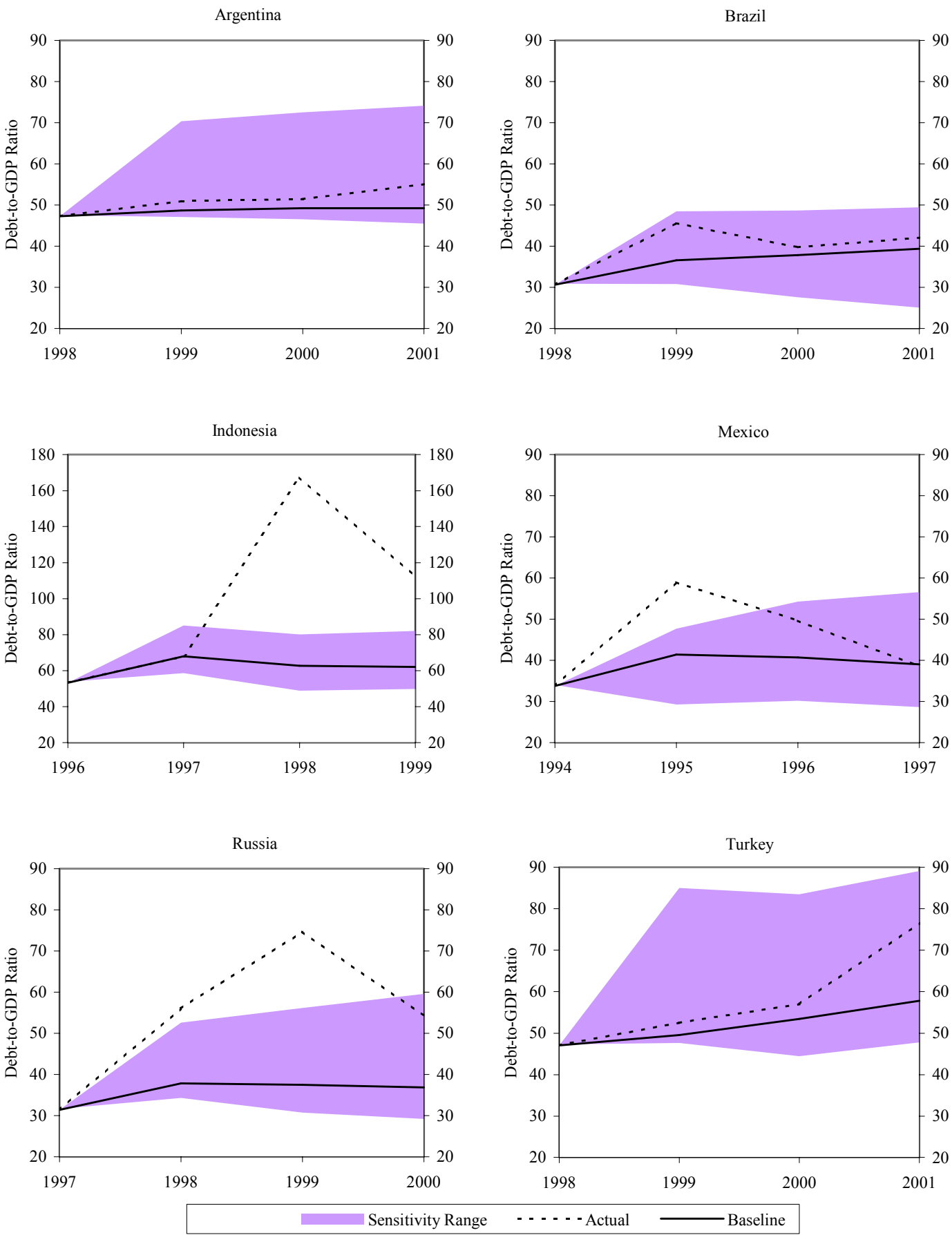

Source: Executive Board documents and staff estimates. 
- In Mexico, the baseline scenario at the time of program approval indicated that the debt-to-GDP ratio would increase by about 5 percentage points of GDP in three years (after a jump of $7 \frac{1}{2}$ percentage points in the crisis year), largely due to the depreciation of the currency. While the actual outcome three years after the crisis was close to forecasts, the standard sensitivity analysis indicates that the debt-to-GDP ratio could have risen by up to 20 percentage points of GDP (but could also have fallen by up to 10 percentage points).

- $\quad$ The contrasting case is that of Indonesia. Projections in 1997 envisaged an increase by almost 9 percent in the debt-to-GDP ratio until 2000. The outcome, an increase by about 59 percent, could not have been captured by any of the standard tests. However, the test assuming a 30 percent depreciation could have highlighted the risk that materialized when the currency subsequently lost value rapidly, by forecasting an increase in the debt-to-GDP ratio of about 29 percentage points of GDP.

- $\quad$ Not as extreme, but nevertheless disquieting is the case of Russia, where the debt-to-GDP ratio increased by 23 percentage points of GDP three years after the crisis, while projections had envisaged an increase of about 5 percent. Here, however, the actual outcome after three years lay within the range indicated by the sensitivity tests.

- In Brazil, a substantial increase in the debt-to-GDP ratio was programmed; by end-2001, the ratio was expected to increase by almost 9 percentage points of GDP. The sensitivity analysis assuming a 30 percent depreciation indicated, however, that the ratio could increase by up to 19 percentage points. The actual outcome, of $11 \frac{1}{2}$ percentage points, was lower than this result, largely because the slower-than-anticipated build-up of external debt mitigated the impact of a strong depreciation.

- In Argentina, projections in 1999 indicated that the external debt-to-GDP ratio would rise by 2 percentage points of GDP, with a sensitivity analysis indicating that the rise could be as much as 27 percentage points of GDP in the event of a devaluation by 30 percent. A scenario that would have been considered more likely at the time, which assumed lower-than-projected real GDP growth, pointed to an increase in the debt-to-GDP ratio of about 10 percentage points, close to the actual outcome of 8-percentage points.

- $\quad$ Projections in 1999 for Turkey indicated that the debt-to-GDP ratio would rise by 11 percentage points by 2001; a sensitivity analyses indicates that the increase could have been as high as 42 percentage points if a combination of shocks to the exchange rate, interest rates, and real GDP growth occurred. The actual outcome, and increase of the debt-to-GDP ratio by 30 percentage points would thus have been captured in the sensitivity scenarios. 